\title{
Expression of Neuregulins and their Putative Receptors, ErbB2 and ErbB3, Is Induced during Wallerian Degeneration
}

\author{
Steven L. Carroll, ${ }^{1}$ Michele L. Miller, ${ }^{1}$ Paul W. Frohnert, ${ }^{1}$ Susanne S. Kim, ${ }^{1}$ and John A. Corbett ${ }^{2}$ \\ ${ }^{1}$ Division of Neuropathology, Department of Pathology, Washington University School of Medicine, St. Louis, Missouri \\ 63110, and 2Department of Biochemistry and Molecular Biology, St. Louis University School of Medicine, St. Louis, \\ Missouri 63104
}

\begin{abstract}
Schwann cell dedifferentiation and proliferation is a prerequisite to axonal regeneration in the injured peripheral nervous system. The neuregulin (NRG) family of growth and differentiation factors may play a particularly important role in this process, because these axon-associated molecules are potent Schwann cell mitogens and differentiation factors in vitro. We have examined Schwann cell DNA synthesis and the expression of NRGs and their receptors, the erbB membrane tyrosine kinases, in rat sciatic nerve, sensory ganglia, and spinal cord 0-30 d postaxotomy. Analysis of NRG cDNAs from these tissues revealed several novel splice variants and showed that cells endogenous to injured nerve express NRG mRNAs. A selective induction of mRNAs encoding the glial growth factor (GGF) subfamily of NRGs occurs in nerve beginning $3 \mathrm{~d}$ postaxotomy and thus coincides with the onset of Schwann cell DNA synthesis. In later stages of Wallerian degeneration, how-
\end{abstract}

Axotomy of peripheral nerve induces the development of a microenvironment that supports axonal regeneration (Aguayo et al., 1978; Bray et al., 1987; Bandtlow, 1993; Raivich and Kreutzberg, 1993). Establishment of this supportive microenvironment requires that nerve undergo the morphological changes of Wallerian degeneration (Holmes and Young, 1942; Fawcett and Keynes, 1990; Tonge and Golding, 1993), in which axon segments and myelin distal to a site of trauma degenerate (Holmes and Young, 1942) and are phagocytosed by Schwann cells and macrophages (Perry and Brown, 1992). Coincident with axonal degeneration, normally quiescent Schwann cells dedifferentiate and proliferate, an event critically important for the promotion of axonal regeneration (Hall and Gregson, 1977; Pellegrino et al., 1986; Fawcett and Keynes, 1990; Nadim et al., 1990). Thus, identification of the signals regulating Schwann cell dedifferentiation, proliferation, and migration during Wallerian degeneration is of great interest.

In vitro proliferation studies using neonatal rat sciatic nerve

Received Sept. 27, 1996; revised Dec. 2, 1996; accepted Dec. 10, 1996.

This work was supported in part by Grant 36-37\#4 from the American Cancer Society (I.R.G.) and a Howard Hughes Medical Institute Pilot Research Grant (S.L.C.). We thank Drs. Kevin Roth, Robert Schmidt, Eugene Johnson, William Snider, and Josh Sanes for helpful comments on this manuscript. We especially thank Dr. Roth for communicating the details of his "dilutional neglect" immunohistochemical technique before publication and Bill Coleman for assistance with confocal microscopy. We also gratefully acknowledge Angela Schroeder for assistance with figure preparation.

Correspondence should be addressed to Dr. Steven L. Carroll, Department of Pathology, Division of Neuropathology, Box 8118, 660 South Euclid Avenue, Washington University School of Medicine, St. Louis, MO 63110.

Copyright (C) 1997 Society for Neuroscience $0270-6474 / 97 / 171642-18 \$ 05.00 / 0$ ever, Schwann cell mitogenesis markedly decreases, whereas elevated GGF expression persists. Of the four known erbB kinases, Schwann cells express both erbB2 and erbB3 receptors over the entire interval studied. Expression of erbB2 and erbB3 is coordinately induced in response to axotomy, indicating that Schwann cell responses to NRGs may be modulated by changes in receptor density. Neuregulin (including transmembrane precursors) and erbB protein are associated with Schwann cells postaxotomy. Thus, in contrast to the concept of NRGs as axon-associated mitogens, our findings suggest that NRGs produced by Schwann cells themselves may be partially responsible for Schwann cell proliferation during Wallerian degeneration, probably acting via autocrine or paracrine mechanisms.

Key words: neuregulins; glial growth factor; Schwann cell; erbB receptor; Wallerian degeneration; autocrine; paracrine

Schwann cells have led to the identification of a group of potent Schwann cell mitogens known as the glial growth factors (GGFs) (Brockes et al., 1980; Goodearl et al., 1993). Cloning of GGF cDNAs demonstrated that these proteins are translated from alternatively spliced mRNAs transcribed from a single gene (Marchionni et al., 1993) that encodes a family of growth and differentiation factors, including the heregulins (Holmes et al., 1992), neu differentiation factor (NDF) (Wen et al., 1992), acetylcholine receptor-inducing activity (Falls et al., 1993), and sensory and motor neuron-derived factor (SMDF) (Ho et al., 1995). Because these factors all induce tyrosine phosphorylation of the neu (also known as HER2 and c-erbB2) proto-oncogene (Falls et al., 1993; Marchionni et al., 1993), they are collectively referred to as the neuregulins (NRGs) (Peles and Yarden, 1993). In addition to their in vitro mitogenic effects, the neuregulins may act as axonderived signals influencing Schwann cells during development. Axon-associated neuregulins have been implicated in promoting neural crest cell differentiation into Schwann cells (Shah et al., 1994), preventing the apoptotic death of pre- and neonatal Schwann cells (Dong et al., 1995; Lee et al., 1995; Marchionni, 1995; Trachtenberg and Thompson, 1996) and as a component of the "axon-associated mitogen" expressed by neonatal sensory neurons (Morrissey et al., 1995). In light of these in vitro and developmental activities, it is highly likely that members of the neuregulin family promote Schwann cell proliferation during Wallerian degeneration of adult peripheral nerve, possibly acting as an axon-derived mitogen.

In this report, we determined (1) whether NRG mRNA and protein are present in sciatic nerve before and during the period 
of maximal Schwann cell DNA synthesis; (2) which NRG isoforms are present and what their likely sources are; (3) whether Schwann cells bear the receptors necessary for responsiveness to NRGs; and (4) whether the types of erbB receptors expressed change as Schwann cells cease proliferation and move into a new, quiescent differentiated state. Although we have found that these molecules are indeed expressed in a pattern consistent with a role as mediators of Schwann cell proliferation, several of our results were unexpected and indicate that the role of neuregulins in Wallerian degeneration is likely to be complex.

\section{MATERIALS AND METHODS}

Animals and surgical procedures. Adult male Harlan Sprague Dawley rats (200-300 gm) were obtained from Sasco (Omaha, NE). All animals were handled in accordance with the guidelines of National Institutes of Health Guide for the Care and Use of Laboratory Animals.

Rats were anesthetized by inhalation of methoxyfluorane (Metofane). Unilateral axotomies were produced by exposing the sciatic nerve in the midgluteal region, transecting it at the sciatic notch, and reflecting the distal segment caudally to prevent regeneration. Crush injuries were similarly produced by crushing the nerve at the sciatic notch with jeweler's forceps. Wounds were carefully sutured shut and animals were allowed to recover. Water and food were provided ad libitum until the rats were killed.

PCR and subcloning. Unless otherwise dictated by the desired target sequence, oligonucleotides were designed with the aid of PrimerSelect software (Windows version 3.01a, DNAStar, Madison, WI). Our designation of neuregulin domains follows the suggestion of Peles and Yarden (1993). Oligonucleotides for the immunoglobulin-like domain of neuregulin correspond to nucleotides 169-193 and 481-501 of rat neu differentiation factor (GenBank accession no. M92430) (Wen et al., 1992). The common forward oligonucleotide for PCR of the epidermal growth factor (EGF)-like domains and the adjacent juxtamembrane segments represents nucleotides 867-895 of rat neuregulin (GenBank accession no. U02323) (Wen et al., 1994); the common (recognizes sequences immediately carboxy to juxtamembrane domains 1,2 , and 4 ) reverse oligonucleotide for PCR of the same domains corresponds to nucleotides 1067-1049. The specific " 1 " juxtamembrane domain reverse oligonucleotide was designed from the sequence of a rat $\beta 1$ splice variant clone isolated with the common EGF-like/juxtamembrane oligonucleotides (clone pSLC120) and has the sequence AGTTCCTCCGCTTCCATAAAT. The specific "3" juxtamembrane domain reverse oligonucleotide corresponds to nucleotides 731-710 of a $\beta 3$ splice variant (GenBank accession no. U02315) (Wen et al., 1994). The specific "4" juxtamembrane domain reverse oligonucleotide corresponds to nucleotides 1124 1101 of a $\beta 4$ a splice variant (GenBank accession no. U02322) (Wen et al., 1994). Oligonucleotides for PCR of the neuregulin "mesenchymal" $N$ terminus correspond to nucleotides $358-381$ and 535-558 of a rat cDNA (GenBank accession no. U02318) (Wen et al., 1994). Oligonucleotides used for PCR of rat EGF receptor correspond to nucleotides 3122-3142 and 3488-3510 of the mouse sequence (GenBank accession no. U03425) (Luetteke et al., 1994). Oligonucleotides used for PCR of rat c-neu/erbB2 correspond to nucleotides 3216-3236 and 3463-3485 of the published rat sequence (GenBank accession no. X03362) (Bargmann et al., 1986). Oligonucleotides used for PCR of rat erbB3 correspond to nucleotides 2968-2989 and 3475-3498 of the human HER3/erbB3 sequence (GenBank accession no. M34309) (Plowman et al., 1990). Oligonucleotides used for PCR of rat erbB4 correspond to nucleotides 3101-3123 and $3628-3651$ of the human HER4/erbB4 sequence (GenBank accession no. L07868) (Plowman et al., 1993).

Single-stranded cDNA for use as PCR templates in the initial cloning of the neuregulin EGF-like/juxtamembrane domain cDNAs and erbB probes was synthesized from poly $\left(\mathrm{A}^{+}\right)$RNA isolated with oligo-dT cellulose chromatography; the reactions were performed in a $20 \mu \mathrm{l}$ reaction using random hexamers as primers and Moloney murine leukemia virus reverse transcriptase (Superscript Plus, Life Technologies, Gaithersburg, $\mathrm{MD}$ ). After completion of the reactions, specimens were diluted to $100 \mu \mathrm{l}$ with double-distilled water, boiled for $5 \mathrm{~min}$, and stored at $-20^{\circ} \mathrm{C}$ until use. Two microliters of each cDNA was used as a PCR template. PCR was performed for 35 cycles of $94^{\circ} \mathrm{C}$ for $1 \mathrm{~min}, 55^{\circ} \mathrm{C}$ for $1 \mathrm{~min}$, and $72^{\circ} \mathrm{C}$ for 1-2 min (depending on the length of the expected product). Products were then either gel-purified, treated with Klenow fragment of DNA polymerase I for $30 \mathrm{~min}$ at $37^{\circ} \mathrm{C}$ and cloned into the EcoRV site of
pBluescript KS(+) (Stratagene, La Jolla, CA), or chloroform-extracted and cloned without further purification into the EcoRV site of the T-vector pT7Blue (Novagen, Madison, WI). Neuregulin clones were screened with $D d e I$ restriction digestion to distinguish $\alpha$ and $\beta$ subtypes; the diagnostic sizes for specific EGF-like/juxtamembrane domain combinations were determined by direct PCR of bacterial colonies. The identity and orientation of clones were then verified by cycle sequencing using an automated DNA sequencer (ABI model 373A, Applied Biosystems, Foster City, CA). If necessary for the purpose of transcribing riboprobes, fragments from pT7Blue clones were subcloned into pBluescript $\mathrm{KS}(+)$.

The designation of clones isolated in this way and the encoded domains are as follows: pSLC111, immunoglobulin-like domain of NRG; pSLC118, $\alpha 2$ EGF-like/variable domain; pSLC120, $\beta 1$ EGF-like/variable domain; pSLC121, $\beta 2$ EGF-like/variable domain; pSLC149, $\beta 3$ EGF-like/ variable domain; pSLC153, $\beta 4$ EGF-like/variable domain; pSLC163, rat EGFR cytoplasmic domain; pSLC162, rat c-neu cytoplasmic cDNA; pSLC125, rat erbB3 cytoplasmic domain; pSLC112, rat erbB4 cytoplasmic domain. A rat c-neu probe (neu c(t)pSP6400) was also obtained from the American Type Culture Collection (Rockville, MD). The complete sequence of the rat EGF, erbB3, and erbB4 receptor cDNAs has been deposited in GenBank and may be found under accession nos. U52529, U52530, and U52531, respectively.

Construction and screening of $c D N A$ libraries. Equal amounts of poly $\left(\mathrm{A}^{+}\right) \mathrm{RNA}$ isolated from $16 \mathrm{hr}, 3 \mathrm{~d}$, and $7 \mathrm{~d}$ postaxotomy nerve segments (both proximal and distal to the axotomy site) were used to synthesize cDNA by the technique of Gubler and Hoffman (1983); a Not I oligo-dT primer-adaptor (Promega, Madison, WI) was used for the first strand synthesis. After treatment with T4 DNA polymerase and DNA polymerase I (Klenow fragment), double-stranded cDNA was ligated to $E c o$ RI linkers and then digested with EcoRI and NotI. cDNAs larger than 500 bp were excised from a $1 \%$ agarose gel, purified (Gene-Clean; BIO101, Vista, CA), and ligated to EcoRI/NotI digested and phosphatased $\lambda$ ZAPII (Stratagene) arms. Ligated phage was packaged (Gigapack Gold, Stratagene) and plated on Escherichia coli (XL-1 Blue strain, Stratagene). A total of $1.2 \times 10^{6}$ primary recombinants was produced in three separate syntheses, pooled, and amplified (Maniatis et al., 1990). A rat brainstem/spinal cord library was purchased from Stratagene (936521).

The axotomized nerve and spinal cord libraries were plated at high density (50,000 plaques/150 mm plate), and duplicate filter lifts were prepared from each plate (Maniatis et al., 1990). ${ }^{32} \mathrm{P}$-labeled probe was generated by the random oligonucleotide priming method (Feinberg and Vogelstein, 1984) with a commercial kit (Boehringer-Mannheim Biochemicals, Indianapolis, IN) and hybridized to filters representing a total of $5 \times 10^{5}$ plaque-forming units from each library under high stringency conditions $(50 \%$ formamide $/ 5 \times$ saline-sodium phosphate-EDTA $/ 5 \times$ Denhardt's $/ 0.1 \%$ SDS at $42^{\circ} \mathrm{C}$ ). Filters were washed four times in $2 \times$ $\mathrm{SSC} / 0.1 \% \mathrm{SDS}$ at room temperature and then twice more in $0.2 \times$ $\mathrm{SSC} / 0.1 \%$ SDS at $68^{\circ} \mathrm{C}$. After isolation of clones by limiting dilution (Maniatis et al., 1990), plasmid was rescued from $\lambda$ phage by coinfecting XL-1 Blue mrf' bacteria with the $\lambda$ phage and ExAssist helper phage (Stratagene) and subsequent passage of the rescued single-stranded phagemid through SOLR bacteria (Stratagene). Four neuregulin cDNAs were isolated from the spinal cord library: pSLC132, a kringle- $\beta 1$ a clone; pSLC133, an SMDF- $\beta 1$ a clone; pSLC134, an SMDF- $\beta 1$ cDNA; and pSLC135, an SMDF- $\beta 1$ a cDNA. Fifty-four erbB3 cDNAs were isolated from the axotomized sciatic nerve library; one of these cDNAs, pSLC138, was extensively characterized and used for the studies detailed in this work. A single erbB4 cDNA, pSLC136, was isolated from the spinal cord library and similarly characterized.

RNA isolation and Northern blot analysis. Total cellular RNA was isolated from tissues using either the method of Chomczynski and Sacchi (1987) or a commercial kit (RNeasy Total RNA kit, Qiagen, Chatsworth, CA). RNA concentrations were determined spectrophotometrically and verified by visualization on agarose gels. For Northern blot analysis, RNA samples and size standard markers (Novagen) were separated on $1 \%$ agarose $/ 2.2 \mathrm{M}$ formaldehyde gels, transferred to Sureblot nylon membranes (Oncor, Gaithersburg, MD), and baked according to the manufacturer's instructions. DNA probes were gel-purified (Gene-Clean kit, BIO101) and labeled by random oligonucleotide priming (Feinberg and Vogelstein, 1984) using a commercial kit (Boehringer-Mannheim). Prehybridization was performed in buffer containing $45 \%$ formamide $/ 5 \times$ $\mathrm{SSC} / 10 \%$ dextran sulfate $/ 1 \% \mathrm{SDS} / 100 \mathrm{mg} / \mathrm{ml}$ salmon sperm DNA $/ 1$ $\mathrm{mg} / \mathrm{ml}$ polyA. Hybridization was performed in the same buffer with $5 \times 10^{5} \mathrm{cpm}$ of probe $/ \mathrm{ml}$ at $45^{\circ}$ for $16-24 \mathrm{hr}$. Blots were then washed three 
times in $2 \times \mathrm{SSC} / 0.5 \% \mathrm{SDS}$ at room temperature $(20 \mathrm{~min} /$ wash $)$ followed by two washes at $68^{\circ} \mathrm{C}$ in $0.2 \times \mathrm{SSC} / 0.5 \% \mathrm{SDS}(1 \mathrm{hr} /$ wash $)$. Blots were then either exposed to Kodak XAR-5 film at $-70^{\circ} \mathrm{C}$ with intensifying screens or analyzed with a PhosphorImager (Molecular Dynamics, Sunnyvale, CA).

The mesenchymal $\mathrm{N}$ terminus probe used for our Northern blot analyses is a 201 bp PCR fragment generated from a small intestine template and verified by sequence analysis (pSLC178). The SMDF $\mathrm{N}$ terminus probe is a $1050 \mathrm{bp}$ fragment from a SMDF- $\beta 1$ a cDNA (pSLC135). The GGF kringle domain probe is a 480 bp NotI fragment from a kringle- $\beta 1$ a cDNA (pSLC132).

Bromodeoxyuridine incorporation studies. The sciatic nerve of $200-$ 300 gm adult male Harlan Sprague Dawley rats was exposed and transected or crushed at the sciatic notch as described above (see Animals and surgical procedures). At specified times after injury, animals were injected intraperitoneally with a mixture of $15 \mathrm{mg} / \mathrm{ml}$ bromodeoxyuridine (BrdU; Sigma B-5002, St. Louis, MO) and 1.5 $\mathrm{mg} / \mathrm{ml} \mathrm{5-fluorouracil} \mathrm{(Sigma} \mathrm{F-0503)} \mathrm{in} 7 \mathrm{~mm} \mathrm{NaOH} / 0.85 \% \mathrm{NaCl}$ (4 $\mathrm{ml} / \mathrm{kg}$ ). Ninety minutes after injection of the BrdU solution, animals were killed, and the tissues of interest were dissected and placed in Bouin's fixative overnight at $4^{\circ} \mathrm{C}$. Tissues were then embedded in paraffin, and serial, $5 \mu \mathrm{m}$ sections were cut and mounted on SuperFrost Plus slides (Fisher Scientific, Pittsburgh, PA).

Every fifth section from each set of slides was deparaffinized, rehydrated through graded alcohols to $1 \times$ PBS, and then microwaved for 3 min in the same buffer. After a 15 min incubation in blocking buffer $(1 \%$ bovine serum albumin $/ 0.2 \%$ powdered milk $/ 0.3 \%$ Triton $\mathrm{X}-100)$, sections were incubated overnight at $4^{\circ} \mathrm{C}$ with goat $\alpha \operatorname{BrdU}$ antiserum $(1: 10,000$ dilution in blocking buffer; antibody kindly provided by Dr. Steven Cohn, Washington University School of Medicine, St. Louis, MO). The next morning, slides were washed three times in $1 \times$ PBS (5 min/wash) and then incubated for $1 \mathrm{hr}$ at room temperature with gold-conjugated rabbit anti-goat antiserum (Amersham Life Sciences, Buckinghamshire, England; 1:40 dilution in blocking buffer). Slides were then washed three times with $1 \times$ PBS ( $5 \mathrm{~min} /$ wash) followed by three $5 \mathrm{~min}$ washes in distilled water. Staining was silver-intensified using a commercial kit (Amersham Life Sciences), and slides were counterstained with hematoxylin. Slides were dehydrated and mounted with Permount (Fisher Scientific).

For analysis, slides were visualized with epi-illumination and brightfield optics. Coded slides were photographed at $400 \times$ magnification, and the number of labeled and total nuclei was determined by an independent observer; labeled cells outside the endoneurium and those within the vasculature were excluded from these counts. Schwann cells were readily verified in these analyses by their oval, blunt-ended nuclei oriented longitudinally relative to the long axis of the nerve; these criteria have been found to be reliable in earlier analyses of peripheral nerve DNA synthesis (Bradley and Asbury, 1970).

Production of a pan-neuregulin polyclonal antibody. A 13 amino acid peptide (sequence FTVKDLSNPSRYL) corresponding to a portion of the rat neuregulin EGF-like common domain was synthesized on a multiple-antigen peptide (MAP) carrier core (Research Genetics, Huntsville, AL). Primary immunization of New Zealand white rabbits was performed by subcutaneous injection of MAP peptide emulsified with an equal volume of complete Freund's adjuvant, with booster injections performed 2,6 , and 10 weeks after the primary injection $(0.5 \mathrm{mg}$ peptide/ injection emulsified with incomplete Freund's adjuvant). Antipeptide antibody titers were monitored by ELISA using MAP peptide-coated plates $(1 \mu \mathrm{g} /$ well $)$. Three rabbits mounted high antipeptide antibody titers; 10 week postimmunization sera from these animals were pooled, and antipeptide antibodies were purified from this serum pool by passage over a peptide/Sepharose affinity column. High-titer fractions, as identified by ELISA, were pooled, aliquoted, and stored at $4^{\circ} \mathrm{C}$. Only affinitypurified pan-neuregulin antiserum was used in the experiments described in this work.

In addition to the characterization of the pan-neuregulin antibodies by Western blotting and immunohistochemistry described in Results (see below), the staining pattern of this antiserum was examined in adult skeletal muscle and dorsal root ganglia and compared with the patterns reported previously with other anti-neuregulin antibodies. In skeletal muscle, small intramuscular nerves and muscle surface "plaques" morphologically consistent with neuromuscular junctions were intensely stained in a pattern very similar to earlier reports (Freeman et al., 1994; Goodearl et al., 1995; Jo et al., 1995; Sandrock et al., 1995). In keeping with the results of Sandrock et al. (1995), the pan-neuregulin antiserum also stained the cell bodies of most, if not all, adult dorsal root ganglion (DRG) neurons. Antibody staining was not observed in these tissues in the absence of primary antibody and was specifically blocked by preincubation with the immunizing peptide.

Antisera and immunohistochemical reagents. Rabbit polyclonal antibodies and the corresponding peptides to the EGF receptor ( $\mathrm{sc}-03)$, erbB2/ c-neu (sc-284), erbB3 (sc-285), erbB4 (sc-283), neuregulin transmembrane precursors with an "a" $\mathrm{C}$ terminus (sc-348), and neuregulin splice variants with a "3" juxtamembrane domain ("secreted" forms; sc-347) were obtained from Santa Cruz Biotechnology (Santa Cruz, CA). Rabbit anti-S100 $\beta$ antiserum (Z0311) was from DAKO (Carpinteria, CA). SMI 34 , a mouse monoclonal $\mathrm{IgG}_{1}$ antibody recognizing extensively phosphorylated neurofilament $\mathrm{H}$ and $\mathrm{M}$ subunits, including those in large and small peripheral axons, was purchased from Sternberger Monoclonals (Baltimore, MD). Dichlorotriazinylaminofluorescein (DTAF)- and Cy3conjugated secondary antibodies were obtained from Jackson Immunoresearch Laboratories (West Grove, PA). Tyramide amplification reagents, including streptavidin-horseradish peroxidase, rhodamine-tyramide, blocking reagent, and amplification diluent were purchased from DuPont NEN (Renaissance TSA-Direct (Red); Boston, MA).

Production of recombinant neuregulin. Truncated rat NRG $\alpha 2$ representing the EGF-like and juxtamembrane domains (rNRG $\left.\alpha 2_{168-240}\right)$ was produced using the bacterial expression vector pSLC151, which contains sequence encoding the indicated amino acids under the control of the T7lac promoter in pET22b $(+)$ (Novagen). For expression of protein, pSLC151 was transferred into the BL21(DE3) strain of E. coli. Cultures were grown to an $\mathrm{OD}_{600}$ of 0.6 , and expression was induced with $1 \mathrm{~mm}$ isopropyl-1-thio- $\beta$-D-galactopyranoside (IPTG). Bacterial pellets were boiled for $4 \mathrm{~min}$ in 0.1 vol of SDS sample buffer (see below) and then sonicated for 5-10 sec to lyse the cells. Induced protein of the expected $11 \mathrm{kDa}$ size was readily visualized by Coomassie blue staining by $1 \mathrm{hr}$ postinduction, with maximal protein expression achieved by $3 \mathrm{hr}$ postinduction. Experiments described in this work were performed using total bacterial lysates without further purification of recombinant neuregulin.

Immunoblotting. Tissue and cell line homogenates for immunoblotting were prepared by homogenizing tissue in $19 \mathrm{vol}$ of ice-cold HES buffer (20 mM HEPES, pH 7.4, $1 \mathrm{mM}$ EDTA, $250 \mathrm{~mm}$ sucrose) containing 2 $\mu \mathrm{g} / \mathrm{ml}$ aprotinin and $2 \mathrm{~mm}$ phenylmethylsulfonyl fluoride. Protein concentrations were determined with a modified Lowry method (DC Protein Assay, Bio-Rad, Hercules, CA). Samples were separated on $8 \%$ SDSpolyacrylamide gels and transferred to nitrocellulose membranes $(0.45$ $\mu \mathrm{m}$; Hoefer, San Francisco, CA). Transfer was accomplished by electroblotting overnight at $40 \mathrm{~mA}$ in $25 \mathrm{~mm}$ Tris, $\mathrm{pH} 8.3,0.192 \mathrm{M}$ glycine, and $20 \%$ methanol. After transfer, equivalent transfer was verified by Coomassie blue staining of residual protein in the gel. Membranes were blocked at $4^{\circ} \mathrm{C}$ overnight or for $2 \mathrm{hr}$ at room temperature with $5 \%$ nonfat dry milk in $1 \times$ TBST $(0.15 \mathrm{M} \mathrm{NaCl}, 10 \mathrm{~mm}$ Tris, pH 8.0, 0.05\% Tween 20 , $0.002 \%$ sodium azide). Primary antibodies were diluted with $1 \%$ nonfat dry milk in $1 \times$ TBST. Horseradish peroxidase-conjugated goat antirabbit secondary antibody (Jackson Immunoresearch Laboratories) was used at a 1:7000 dilution in $1 \times$ TBST. Immunoreactive species were identified by enhanced chemiluminescence (Amersham).

Immunohistochemistry. At specified times after axotomy, rats were anesthetized by Metofane inhalation and perfused transcardially with room temperature $0.85 \%$ saline followed by room temperature $4 \%$ paraformaldehyde in $1 \times$ PBS. Tissues of interest were dissected and postfixed overnight at $4^{\circ} \mathrm{C}$ in $4 \%$ paraformaldehyde in $1 \times$ PBS. After a rinse in ice-cold $1 \times \mathrm{PBS}$, tissues were infiltrated at $4^{\circ} \mathrm{C}$ for $48 \mathrm{hr}$ with $10 \%$ sucrose in $1 \times$ PBS and then embedded in TBS tissue-freezing medium (Triangle Biomedical Sciences, Durham, NC). Eight micrometer cryostat sections were thaw-mounted on SuperFrost Plus slides (Fisher Scientific) and stored at $-20^{\circ} \mathrm{C}$ until use.

For conventional single- and double-label immunohistochemistry, nonspecific binding was blocked by incubation for $20 \mathrm{~min}$ at room temperature with PBS blocking buffer (0.1 M PBS, $\mathrm{pH} 7.4,1 \%$ bovine serum albumin, $0.2 \%$ powdered milk, $0.3 \%$ Triton X-100). Primary antibodies diluted in PBS blocking buffer were applied overnight at $4^{\circ} \mathrm{C}$. After three PBS rinses, sections were incubated for $1 \mathrm{hr}$ at room temperature with DTAF- (1:100 dilution) and/or Cy3- (1:200 dilution) conjugated secondary antibodies diluted in PBS blocking buffer. Sections were then washed three times with PBS and mounted in 1:1 PBS/glycerol. Control sections were incubated without primary antibodies to identify potential nonspecific binding of the secondary antibodies. In addition, the specificity of the observed immunostaining was confirmed by preincubating antisera with either immunizing peptide or a nonrelated peptide in concentrations 
spanning four orders of magnitude $(10 \mu \mathrm{g} / \mathrm{ml}$ to $10 \mathrm{ng} / \mathrm{ml}$ of peptide); in all instances, preabsorption at the higher concentrations of immunizing peptide abolished the staining pattern of the primary antibody, with lower peptide concentrations demonstrating progressively stronger (albeit still diminished) immunostaining. Preincubation with nonrelated peptide had no effect on the staining pattern of the primary antibodies.

For double-label immunohistochemical experiments in which both primary antibodies were raised in rabbit, the recently developed technique of "dilutional neglect" immunohistochemistry was used (Shindler and Roth, 1996). In preliminary experiments, it was determined that peripheral nerve $\mathrm{S} 100 \beta$ immunoreactivity is readily detectable with rhodamine-tyramide amplification at a primary antibody dilution of 1:10,000, whereas $\mathrm{S} 100 \beta$ immunostaining is undetectable in this same tissue with conventional immunohistochemistry when the primary antibody is diluted greater than 1:4000. For double-label immunohistochemistry, anti-S100 $\beta$ antiserum (1:10,000 dilution) diluted in PBS blocking buffer was first applied to tissue sections overnight at $4^{\circ} \mathrm{C}$. After three PBS washes, biotinylated donkey anti-rabbit antibody diluted in PBS blocking buffer (1:1000) was applied for $1 \mathrm{hr}$ at room temperature. Sections were again rinsed three times with PBS and then incubated in TNB buffer $(0.1 \mathrm{M}$ Tris- $\mathrm{HCl}, \mathrm{pH} 7.5,0.15 \mathrm{M} \mathrm{NaCl}, 0.5 \%$ DuPont blocking reagent) for 30 min, followed by a $30 \mathrm{~min}$ room temperature incubation with streptavidin-horseradish peroxidase (1:500 dilution in TNB). After three washes with Tris buffer $(0.1 \mathrm{M}$ Tris- $\mathrm{HCl}, \mathrm{pH} 7.5,0.15 \mathrm{M} \mathrm{NaCl})$, rhodaminetyramide (diluted 1:1000 in $1 \times$ amplification diluent; DuPont) was applied to tissue sections for $10 \mathrm{~min}$ at room temperature. Sections were then washed three times with Tris buffer, followed by two washes with PBS. The second primary antibody, diluted in PBS blocking buffer, was then applied to tissue sections and detected with DTAF-conjugated donkey anti-rabbit secondary antibody as described above. Sections were mounted with 1:1 PBS-glycerol before examination. As a control, the second primary antibody was omitted for some slides, resulting in an absence of DTAF staining. Subsequent experiments using conventional double-label immunofluorescence with a mouse anti-S100 $\beta$ antibody (Sigma S2532), in combination with either the erbB or pan-neuregulin antibodies, produced an immunostaining pattern identical to that seen with dilutional neglect immunohistochemistry.

Conventional immunofluorescence images were visualized using a Zeiss-Axioskop microscope equipped for epifluorescence. Confocal immunofluorescent images were obtained using a Molecular Dynamics Sarastro 2000 laser scanning unit coupled to a Zeiss Axioskop microscope equipped with a Zeiss Plan ApoChromat $63 \times$, 1.4 numerical aperture objective. For both rhodamine/DTAF and Cy3/DTAF double-labeled preparations, images were acquired simultaneously using a 488/568 nm primary beam splitter and a $565 \mathrm{~nm}$ secondary beam splitter with the longer wavelength light being passed through a 600DF40 filter and the shorter through a 530DF30 filter on a second photomultiplier tube. It was confirmed that this optical setup resulted in no fluorescent bleedthrough between channels. Images were processed on a Silicon Graphics workstation using the Imagespace software package (Molecular Dynamics). Processing consisted of independent linear scaling of the red and green images, with either no further processing or a single passage through a Gaussian filter.

\section{RESULTS}

\section{Isolation and characterization of neuregulin CDNAs expressed in axotomized sciatic nerve and neuronal populations projecting axons into this nerve}

If the neuregulins promote in vivo Schwann cell mitogenesis during Wallerian degeneration, their availability to Schwann cells should coincide with the onset of DNA synthesis and persist throughout the subsequent period of maximal proliferation. Although it is known that DRG sensory neurons (Marchionni et al., 1993; Orr-Urtreger et al., 1993; Meyer and Birchmeier, 1994; Ho et al., 1995) and motor neurons of the spinal cord ventral horn (Falls et al., 1993; Marchionni et al., 1993; Orr-Urtreger et al., 1993; Chen et al., 1994; Corfas et al., 1995; Ho et al., 1995) express NRGs, no information is available regarding NRG mRNA expression in the nerve itself. Therefore, we used the reverse transcription (RT)-PCR to compare the expression of NRG splice variant mRNAs in axotomized sciatic nerve (reflecting both cell types endogenous to the nerve and responding macrophages) with that of tissues containing the sensory (L4, L5, and L6 DRG) and motor (lumbar enlargement of the spinal cord) neuron populations projecting axons into this nerve. Because functional neuregulin requires an intact EGF-like domain to bind to its receptor(s) and mediate the biological activity of the factor (Wen et al., 1994), we designed our initial PCR primers to span this domain and the adjacent juxtamembrane domain, which modulates the secretion and/or release of the factor (Wen et al., 1994). Rat cDNA clones of the EGF-like and juxtamembrane domains were generated from axotomized nerve (nerve distal to a site of surgical transection $16 \mathrm{hr}, 3 \mathrm{~d}$, and $7 \mathrm{~d}$ postaxotomy) and lumbar spinal cord and DRG ( 7 and 10 d postaxotomy) templates. After initial screening and grouping (for details, see Materials and Methods), sequence analysis confirmed that the isolated clones contain intact, and therefore presumably functional, EGF-like domains. Neuregulin splice variants were readily detectable in axotomized nerve with this analysis. Although it should be noted that the ratios of clonal isolation obtained in these experiments may vary somewhat from the absolute abundance of each splice variant within a tissue, it is nonetheless apparent that neuregulins within axotomized nerve are represented by a population of splice variants (predominantly $\alpha 2$ isoforms) quite distinct from that detected in lumbar DRG and spinal cord (exclusively $\beta 1, \beta 2, \beta 3$, and $\beta 4$ splice variants; Fig. $1 A$ ). These findings, considered together with the typical exclusion of mRNA from the axons of vertebrate neurons, argue that the neuregulin mRNAs detected in axotomized nerve cannot have been entirely derived from the remnants of degenerating axons in the sciatic nerve and thus are likely to originate from cells endogenous to nerve.

In addition to alternative splicing, neuregulin variability is generated further through the probable utilization of at least three alternative promoters [the "mesenchymal," "GGF," and "SMDF" promoters (Peles and Yarden, 1993; Ben-Baruch and Yarden, 1994; Ho et al., 1995)]. This results in the production of NRG splice variants with unique $\mathrm{N}$ termini and allows the neuregulins to be divided into three corresponding subfamilies, each defined by their unique $\mathrm{N}$ terminus. To obtain subfamily-specific probes, the neuregulin EGF-like/juxtamembrane domain clones and a clone of the neuregulin immunoglobulin-like domain (see Materials and Methods) were used to screen normal and axotomized sciatic nerve and spinal cord cDNA libraries for full-length clones of neuregulin. Although no cDNAs were obtained from the sciatic nerve libraries, four neuregulin clones were isolated from the spinal cord library and mapped, and selected regions were sequenced to establish their identity. All of these cDNAs were found to encode previously undescribed transmembrane precursors within the GGF and SMDF neuregulin subfamilies (for the structures of these clones and a delineation of the GGF and SMDF subfamilies, see Fig. $1 B$ ).

\section{GGF expression is induced in axotomized sciatic nerve}

Although our RT-PCR analyses indicated that NRG transcripts are generated by cells within injured nerve, this technique is exquisitely sensitive, and the resulting clones could reflect the contribution of a very minor cell population within this tissue. To make an initial assessment of whether appreciable levels of neuregulin mRNAs are expressed in normal and axotomized sciatic nerve and the neuronal populations projecting axons into this nerve, RNA samples were probed by Northern blotting using a cDNA fragment encoding the extracellular domain of a GGF (kringle- $\beta 1$ a variant) cDNA (Fig. $2 A$ ). This probe, which contains 


\section{A. Axotomized Sciatic Nerve}

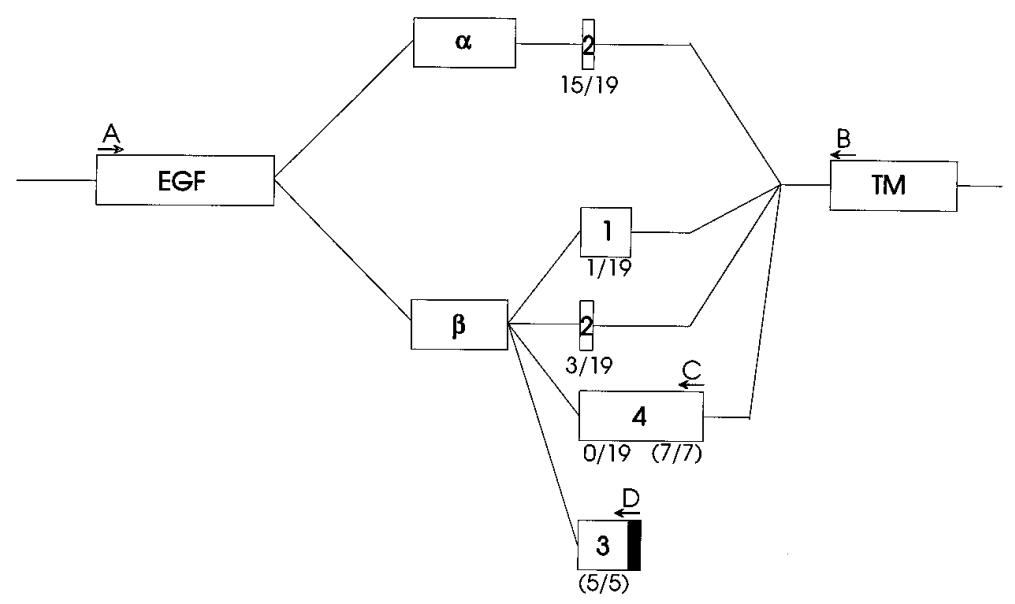

Lumbar DRG and Spinal Cord
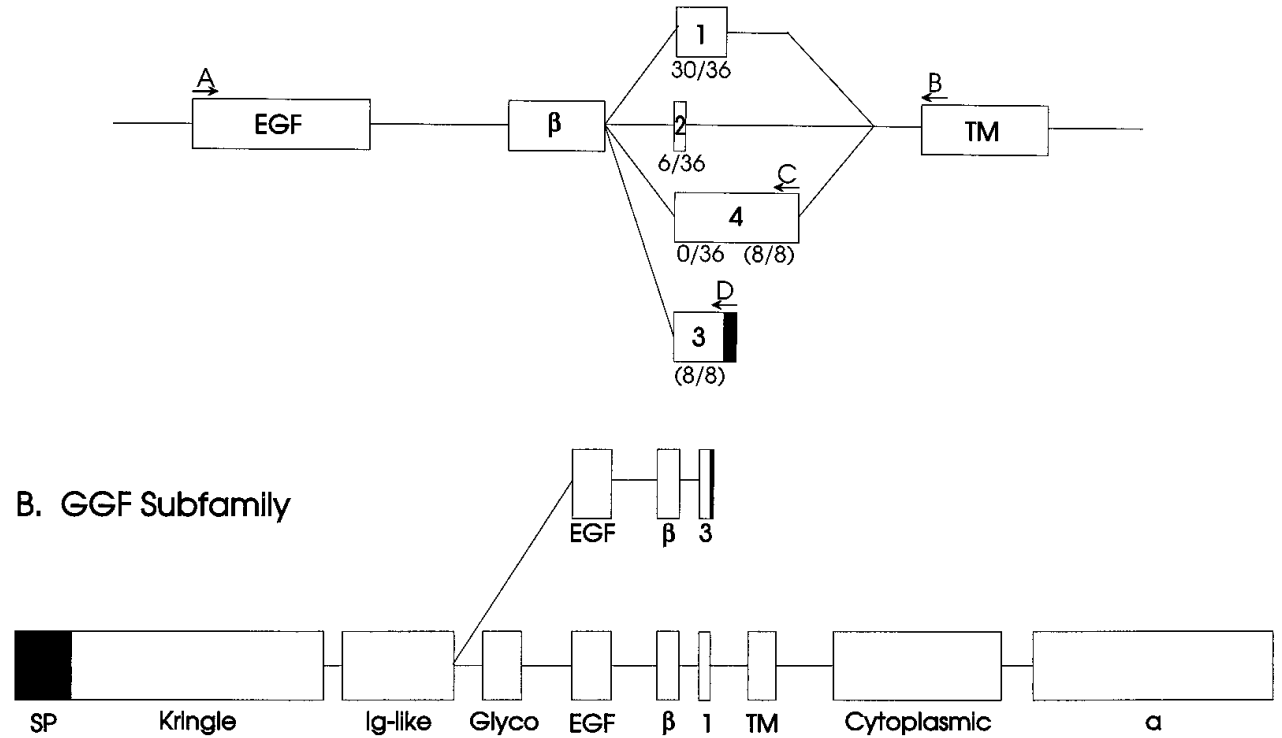

\section{SMDF Subfamily}

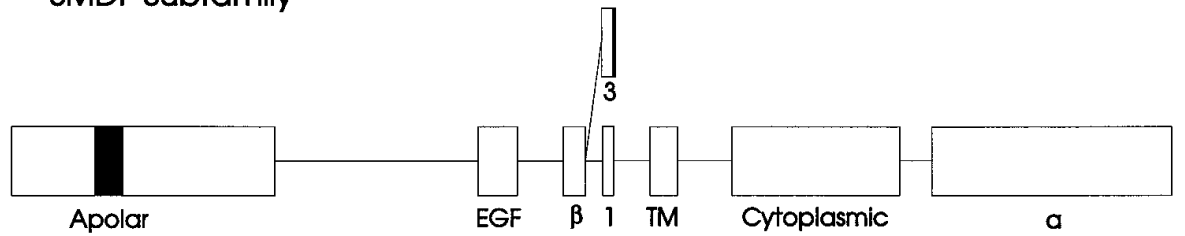

Figure 1. Identification of neuregulin splice variants expressed in axotomized sciatic nerve and the corresponding neuronal populations. $A$, Poly $\left(\mathrm{A}^{+}\right)$ RNA was isolated from a pool of surgically transected sciatic nerve distal to the site of transection collected $16 \mathrm{hr}, 3 \mathrm{~d}$, and $7 \mathrm{~d}$ postinjury and a pool of L4, L5, and L6 dorsal root ganglia and lumbar spinal cord collected 7 and $10 \mathrm{~d}$ postaxotomy. Each RNA pool was reverse-transcribed to cDNA with random hexamer primers and used as templates for PCR with primers, the positions of which are indicated by arrows (modified from Ben-Baruch and Yarden, 1994). Distinctly different subsets of neuregulin splice variants were identified in axotomized sciatic nerve as opposed to the regions of the nervous system projecting axons into this same structure. Regions encompassed by these cDNAs include the EGF-like common domain (EGF), EGF-like variable domains $(\alpha$ or $\beta$ ), the juxtamembrane domains (numbers 1-4), and the transmembrane domain (TM). Note that splice variants with a " 3 " juxtamembrane domain terminate within the juxtamembrane domain (indicated by a dark bar at the $\mathrm{C}$ terminus). Figure legend continues. 
the EGF-like domain common to all NRG splice variants, detected up to three mRNA species with sizes of 2.0, 3.5, and $7.5 \mathrm{~kb}$, with the $2.0 \mathrm{~kb}$ mRNA predominating in all tested tissues. Neuregulin mRNA was readily detectable in tissues containing neurons projecting into the sciatic nerve (lumbar DRG and spinal cord), as well as in brain and skeletal muscle. Expression of neuregulin transcripts in noninjured nerve was compared with that in nerve distal to a site of surgical transection $7 \mathrm{~d}$ postaxotomy. It is interesting that although neuregulin mRNA was undetectable in noninjured nerve, neuregulin mRNA is induced by $7 \mathrm{~d}$ postaxotomy to levels comparable to that seen in spinal cord, a tissue previously reported to demonstrate some of the highest levels of neuregulin mRNA expression in the body (Wen et al., 1992). As a control, this blot also contained RNA from the rat JS1 schwannoma cell line, a line derived from a tumor induced by in utero chemical mutagenesis (Schubert et al., 1974; Kimura et al., 1990). The absolute highest abundance of neuregulin mRNA that we observed was in the JS1 cell line (Fig. 2A).

To more fully characterize the time course of neuregulin mRNA induction in axotomized sciatic nerve, surgical transection of the sciatic nerve was performed under conditions that do not allow axonal regeneration (see Materials and Methods). At specified times (1-30 d postaxotomy), tissues were dissected and used to prepare total cellular RNA; this time course spans the period in which the quiescent Schwann cells of the intact adult nerve dedifferentiate, traverse their period of maximal proliferation, and again withdraw from the cell cycle, entering a new quiescent, dedifferentiated state (see below). A blot of noninjured and postaxotomy nerve RNA over this time course was hybridized to the GGF extracellular domain probe described above (Fig. 2B). Although NRG mRNA was undetectable in noninjured nerve and only faintly seen by $1 \mathrm{~d}$ post-transection, NRG mRNA with the same size distribution seen in Figure $2 A$ was readily detectable by $3 \mathrm{~d}$ postaxotomy and continued to increase in abundance to $30 \mathrm{~d}$ postaxotomy.

Although our results thus far indicated that NRG synthesized within axotomized nerve represented a major potential source of this Schwann cell mitogen, these experiments did not allow us to determine which of the major neuregulin subfamilies these transcripts represented. Replicate RNA blots containing RNA from $7 \mathrm{~d}$ postaxotomy nerve, JS1 cells, and a panel of tissues expected to express one or more NRG splice variants with each $\mathrm{N}$ terminus were therefore probed with cDNA fragments encoding each of the distinct $\mathrm{N}$ termini. A GGF-specific probe recognized primarily the $2.0 \mathrm{~kb}$ mRNA with prominent GGF expression identified in axotomized sciatic nerve, spinal cord, skeletal muscle, and JS1 schwannoma cells (Fig. 2C). Lower levels of GGF transcripts are also present in small and large intestine. In contrast, the SMDF N terminus probe recognized the 3.5 and $7.5 \mathrm{~kb}$ NRG transcripts in JS1 cells (Fig. 2D) and, at much lower levels, in spinal cord (data not shown; see Fig. 2 legend). The mesenchymal $\mathrm{N}$ terminus was not detected in axotomized nerve with Northern blots (data not shown), although a weak signal for these isoforms was detected in subsequent RT-PCR analyses (data not shown). We conclude that GGF forms of NRG represent the major set of the splice variants induced in peripheral nerve by axotomy.

\section{Characterization of a pan-neuregulin antiserum and demonstration that neuregulin protein is induced in sciatic nerve postaxotomy}

Although we found that neuregulin mRNA is induced in sciatic nerve by axotomy, this did not establish when neuregulin protein is potentially available to Schwann cells or with what cell types this protein is associated. The array of neuregulin splice variants raises the questions of whether specific isoforms might be induced postaxotomy and whether different neuregulin splice variants might have distinct cellular distributions. To facilitate study of all neuregulin splice variants, we raised a "pan-neuregulin" antiserum by immunizing rabbits with a peptide sequence found in the EGF-like common domain of all neuregulin isoforms, but not in other molecules with an EGF domain (Holmes et al., 1992; Wen et al., 1992). The specificity of affinity-purified antibodies isolated from these antisera was tested by Western blot analysis of lysates from bacteria expressing the rat NRG $\alpha 2$ EGF-like and juxtamembrane domains (rNRG $\alpha 2_{168-240}$ ) (Ben-Baruch and Yarden, 1994). The pan-neuregulin antibodies recognized a band of $\sim 11$ $\mathrm{kDa}$, the expected size of the bacterially produced NRG fusion protein, in lysates of IPTG-induced cells carrying the neuregulin expression plasmid, but not in similarly induced cells of the same bacterial strain expressing an unrelated antigen, $\beta$-galactosidase (Fig. $3 A$ ); the pan-neuregulin antiserum also recognizes two less intense larger bands, which presumably represent aggregation products of the recombinant protein. Western blot analysis of lysates of spinal cord and DRG from noninjured animals and $5 \mathrm{~d}$ postaxotomy sciatic nerve showed labeling of several protein bands ranging in size from 45 to $100 \mathrm{kDa}$ (Fig. $3 B$ ). Preincubation of the pan-neuregulin antiserum with the immunizing peptide blocked detection of the indicated proteins (Fig. 3B, compare 1 to 2 ). The sizes of the specifically blocked protein species in spinal cord are 100,75 , and $52 \mathrm{kDa}$, which is similar to the immunoblotting results reported previously with other antisera in lysates of this tissue (Sandrock et al., 1995). In preliminary experiments (see also below), antisera raised against other epitopes present in specific neuregulin subsets (transmembrane precursors with "a" C termini, secreted forms with " 3 " juxtamembrane domains) specifically recognized proteins of the same size as detected with our pan-neuregulin antibody.

Protein was prepared from noninjured sciatic nerve and surgically transected nerve at the same time points used for our RNA analyses, and immunoblots of these lysates were probed

\section{$\leftarrow$}

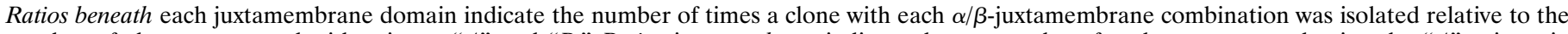

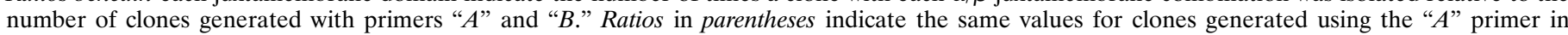

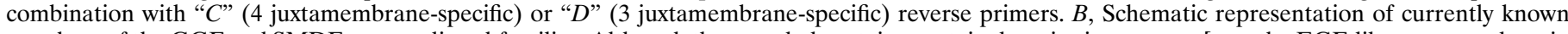

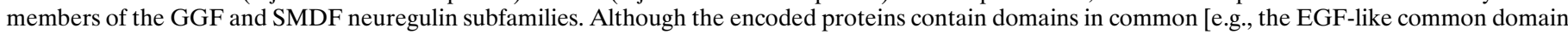

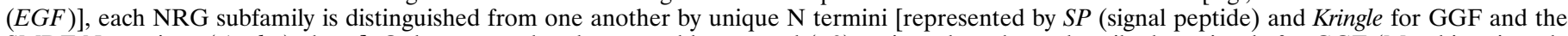

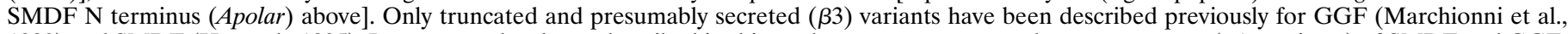

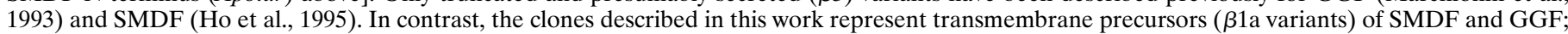

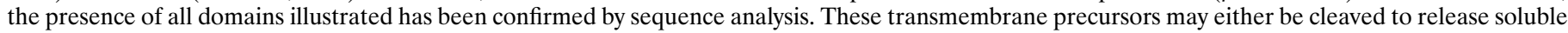

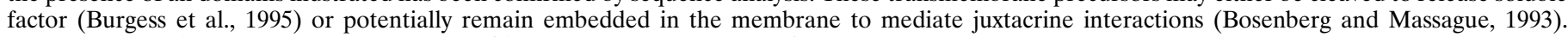

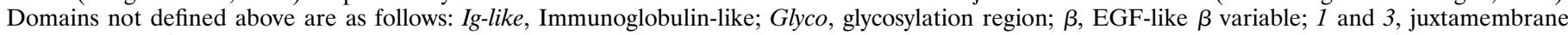
domains; Cytoplasmic, cytoplasmic domain common to all neuregulin transmembrane precursors; $a$, one of three potential neuregulin $\mathrm{C}$ termini. 


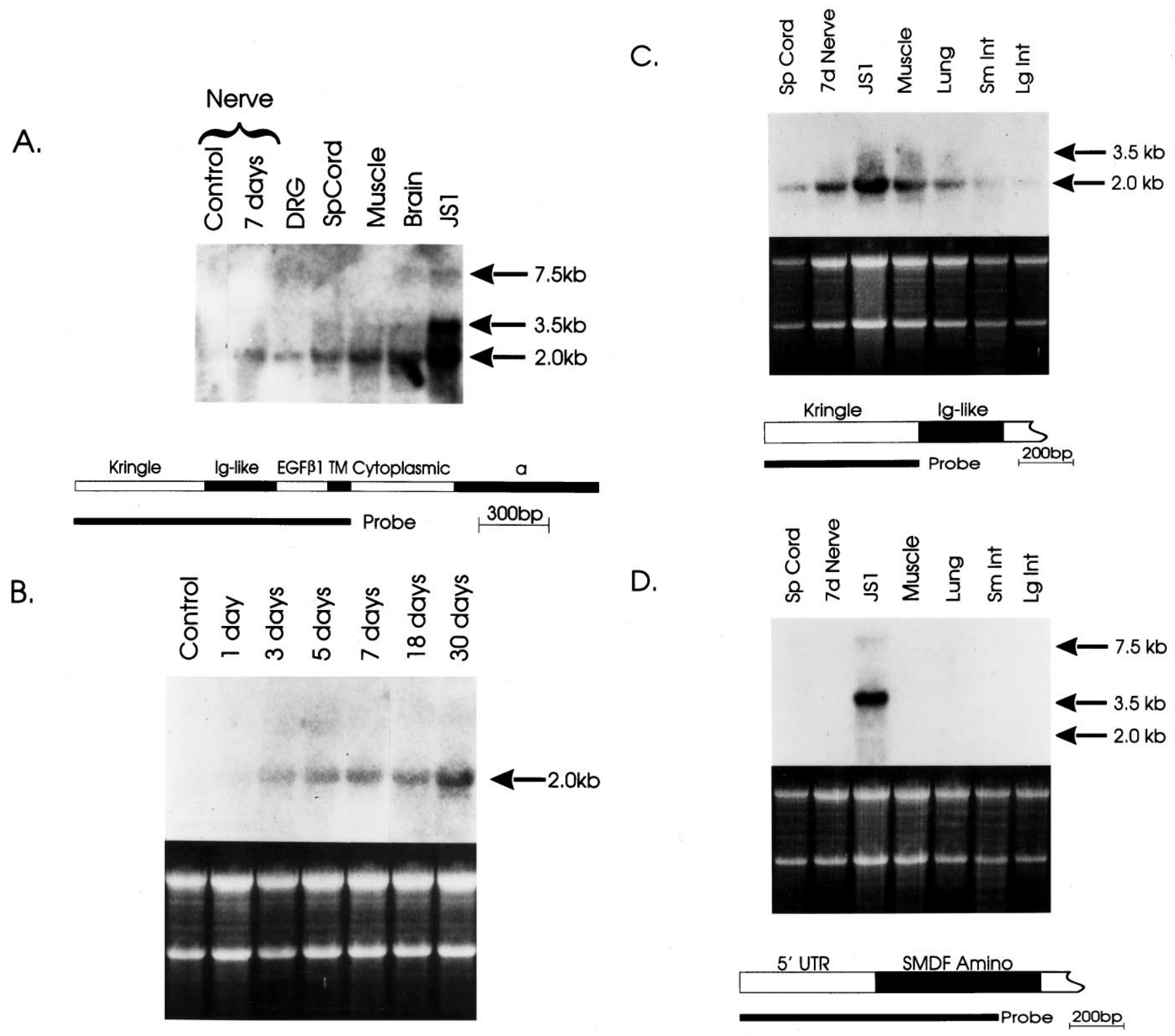

Figure 2. Neuregulin mRNA expression in sciatic nerve is induced by axotomy. A, A cDNA fragment (Probe) spanning the neuregulin transmembrane $(T M)$, EGF-like (EGFß1), immunoglobulin-like (Ig-like), and Kringle domains of a GGF (kringle- $\beta 1$ a) neuregulin splice variant was used to probe a Northern blot $(15 \mu \mathrm{g}$ of total cellular RNA/lane). Up to three mRNA species $(2.0,3.5$, and $7.5 \mathrm{~kb})$ are seen in this exposure. This blot has been purposefully overexposed to demonstrate the presence of the $7.5 \mathrm{~kb}$ transcript. $B$, A total of $10 \mu \mathrm{g}$ per lane of cellular RNA from noninjured (Control) sciatic nerve and the nerve segment distal to a site of surgical transection taken $1,3,5,7,18$, or $30 \mathrm{~d}$ postaxotomy was probed with the same probe used in $A$. Repeat experiments performed with a mixture of GGF, SMDF, and NDF N-terminal probes confirmed these observations and also demonstrated levels of neuregulin mRNA expression at $10 \mathrm{~d}$ postaxotomy similar to those at 7 and $18 \mathrm{~d}$. A photograph of the ethidium bromide-stained gel before transfer is presented beneath the Northern blot to demonstrate the uniform loading of these samples; equivalent transfer was confirmed by examining the membrane under ultraviolet illumination. $C, D$, Northern blots of total cellular RNA (10 $\mu \mathrm{g} / \mathrm{lane})$ isolated from the lumbar enlargement of the spinal cord $(S p C o r d)$, the nerve segment distal to a site of surgical transection $7 \mathrm{~d}$ postaxotomy ( $7 d$ Nerve), JS1 rat schwannoma cells (JS1), gastrocnemius/soleus muscle (Muscle), Lung, small intestine (Sm Int), and large intestine ( $L g$ Int) were probed with the indicated probes, which are specific for the $\mathrm{N}$ termini of GGF $(C)$ or SMDF $(D)$ neuregulin splice variants. Except for the $7 \mathrm{~d}$ postaxotomy nerve, all tissues were collected from animals that had not undergone any surgical manipulation. Expected positions of the 2.0, 3.5, and $7.5 \mathrm{~kb}$ mRNAs are indicated. Note that the GGF probe hybridizes to the $2.0 \mathrm{~kb}$ transcript, whereas the SMDF probe recognizes both the 3.5 and $7.5 \mathrm{~kb}$ mRNAs. Although SMDF expression was most prominent in JS1 cells, longer exposures of this blot also demonstrated mRNAs of the same size in spinal cord (data not shown). Again, photographs of the ethidium bromide-stained gels before transfer are presented below each autoradiograph.

with the pan-neuregulin antibodies, as well as with antibodies directed against the subset of neuregulin transmembrane precursors with an "a" C terminus and "secreted" neuregulins (isoforms with a " 3 " juxtamembrane domain). Analysis of the normal and injured nerve lysates with the pan-neuregulin antiserum demonstrated a complex pattern of immunoreactive species that changed with increasing time after axotomy. Three NRG species $(100,70$, and $55 \mathrm{kDa})$ are detectable in noninjured nerve (Fig. 3C, top). Because NRG mRNA is detectable only with difficulty in noninjured nerve [undetectable by Northern analysis (see above), but detectable by RT-PCR] (S.L.C., unpublished observations), these proteins may be derived from 


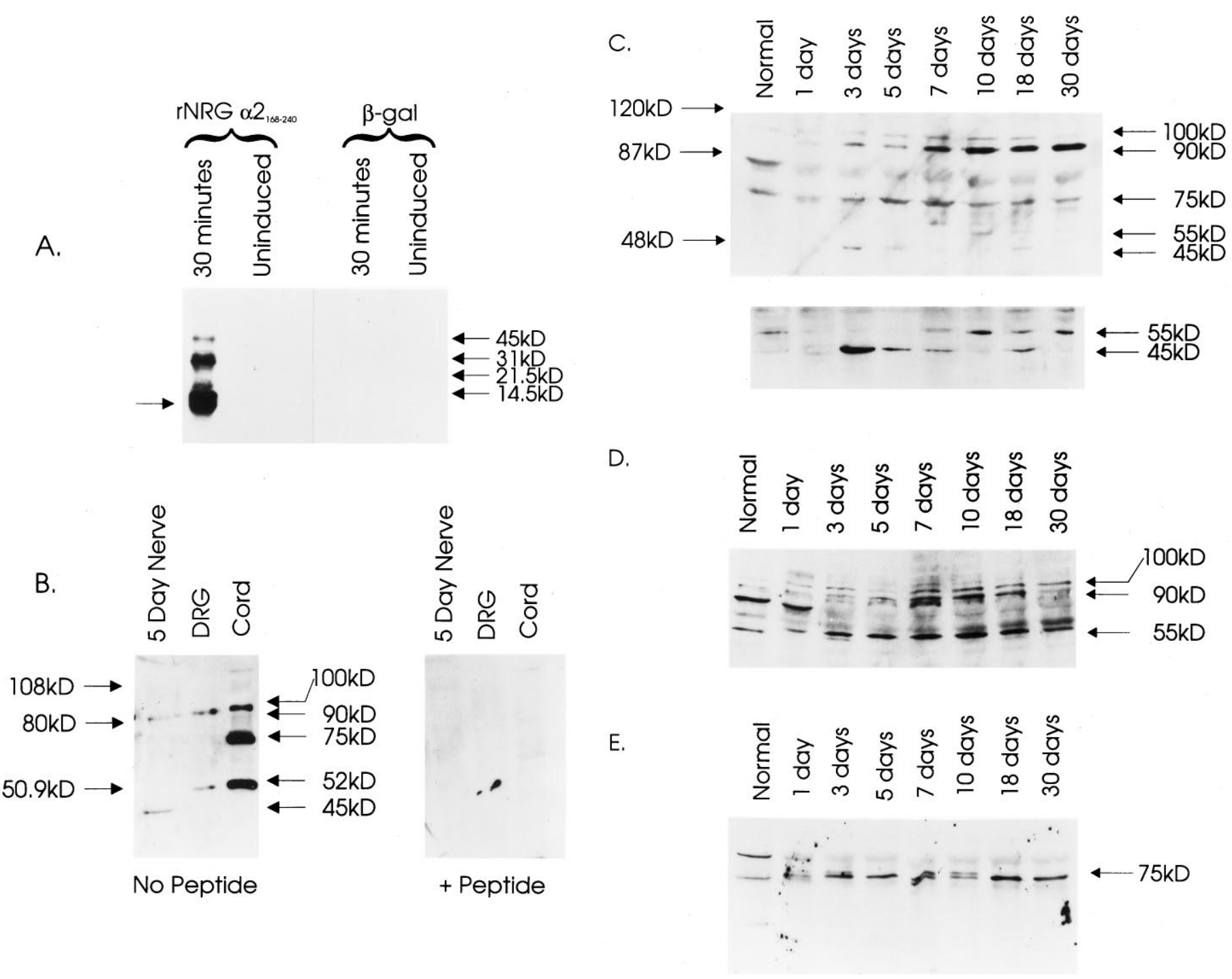

Figure 3. Western blot analysis of neuregulins in axotomized sciatic nerve. $A$, Lysates of bacteria expressing either truncated recombinant rat NRG $\alpha 2$ $\left(\mathrm{rNRG} \alpha 2_{168-240}\right)$ or an unrelated antigen ( $\beta$-galactosidase) were separated on a $15 \%$ gel $(25 \mu \mathrm{g} /$ lane $)$ and probed with the pan-neuregulin antiserum $(1$ $\mu \mathrm{g} / \mathrm{ml})$. The times after IPTG induction and the identity of the induced proteins are indicated above the lanes. The positions of the detected $\mathrm{rNRG} \alpha 2_{168-240}$ (arrow, left) and size markers (arrows, right) are indicated. $B$, The specificity of the pan-neuregulin antiserum was verified by preincubating antiserum $(1 \mu \mathrm{g} / \mathrm{ml})$ for $24 \mathrm{hr}$ at $4^{\circ} \mathrm{C}$ with $10 \mu \mathrm{g} / \mathrm{ml}$ of the immunizing peptide. The pattern of bands detected in immunoblots was then compared for blots probed with the pan-neuregulin antiserum preincubated with no added peptide (left) or the immunizing peptide (right). The sources of the lysates tested (spinal cord and DRG from noninjured animals, $5 \mathrm{~d}$ postaxotomy nerve) are indicated above each lane ( $45 \mu \mathrm{g}$ protein loaded/lane). Size markers are indicated on the left side of the left panel, and specific bands are indicated on the right side of the panel. The bands indicated are the major forms seen in this experiment. With longer exposure, no additional specific bands were seen in the DRG or spinal cord lysates, but in the $5 \mathrm{~d}$ postaxotomy nerve lysate, two other bands ( 100 and $75 \mathrm{kDa})$ became detectable in this and other experiments. $C-E$, Expression of neuregulin protein was examined in lysates of noninjured ( Normal) nerve and the nerve segment distal to a site of surgical transection 1, 3, 5, 7, 10, 18, or $30 \mathrm{~d}$ postsurgery (45 $\mu \mathrm{g}$ protein loaded/lane) using the pan-neuregulin antiserum $(C)$, an antibody directed against the $\mathrm{C}$ terminus of "a" transmembrane precursors $(D)$, and an antibody directed against a peptide from the "3" juxtamembrane domain of GGF $(E)$. Size markers are indicated on the left side of the top panel of $C$, with specific bands indicated by arrows on the right side of each panel in $C, D$, and $E$. The bottom panel in $C$ is a longer exposure of a second immunoblot performed to highlight the 45 and $55 \mathrm{kDa}$ bands. In $D$, note also that the "a" neuregulin antibody recognizes a $55 \mathrm{kDa}$ band beginning $1-3 \mathrm{~d}$ postaxotomy; although this band is specifically blocked by preincubation of the antiserum with immunizing peptide (data not shown), it may be too small to represent a complete NRG transmembrane precursor, and its precise identity is currently unclear. In $E$, a slightly larger band is seen in the 7 and $10 \mathrm{~d}$ postaxotomy nerve lysates. Although this band is specifically blocked by preincubation with the immunizing peptide, it was not observed in immunoblots performed with the pan-neuregulin antiserum.

axonally associated NRGs or a relatively stable population of molecules produced by cells endogenous to the nerve. After axotomy, the relative abundance of the 55 and $70 \mathrm{kDa}$ NRGlike forms diminishes rapidly. By $3 \mathrm{~d}$ postaxotomy, three other NRG-like immunoreactive proteins $(45,75$, and $90 \mathrm{kDa})$ are increasing in abundance. The 75 and $90 \mathrm{kDa}$ proteins continue to increase in abundance through $30 \mathrm{~d}$. The $45 \mathrm{kDa}$ species, however, peaks in abundance $3 \mathrm{~d}$ postaxotomy and gradually declines thereafter, last detectable at $18 \mathrm{~d}$ postaxotomy (for a longer exposure demonstrating these changes, see Fig. $3 C$, bottom). A $55 \mathrm{kDa}$ immunoreactive protein is again detected $7-10 \mathrm{~d}$ postaxotomy and persists to $30 \mathrm{~d}$ after injury (Fig. $3 C$, bottom). The identity of at least a portion of the protein in some of these induced bands was clarified further by immuno- 
A.
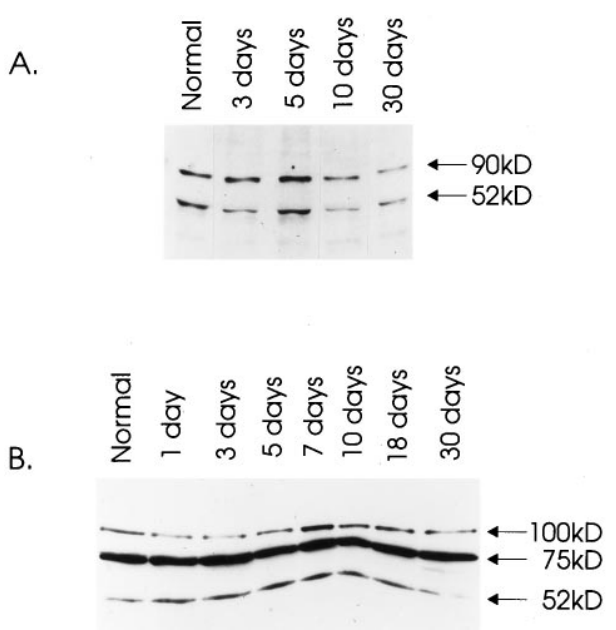

Figure 4. Western blot analysis of neuregulins in postaxotomy spinal cord and DRG. The pan-neuregulin antiserum was used to probe immunoblots of lysates of lumbar dorsal root ganglia (L4 and L5 DRG; $A$ ) and spinal cord $(B)$ collected from noninjured (Normal) and axotomized animals at the indicated times postaxotomy ( $45 \mu \mathrm{g} / \mathrm{ml}$ protein loaded/lane). No induced neuregulin proteins were identified in either tissue. The position of specific neuregulin proteins is indicated (arrows).

blotting with two additional antisera. An antibody directed against neuregulin precursors with an "a" C terminus specifically labeled proteins at the same positions as the 90 and 100 $\mathrm{kDa}$ species recognized by the pan-neuregulin antiserum (Fig. $3 D$ ), as well as a $55 \mathrm{kDa}$ protein (see figure legend). Similarly, antiserum recognizing the " 3 " juxtamembrane domain specifically detected a protein migrating at the same position as the 75 $\mathrm{kDa}$ polypeptide labeled by the pan-neuregulin antiserum (Fig. $3 E$ ). These results demonstrate that NRG-like immunoreactive proteins are induced by $3 \mathrm{~d}$ postaxotomy, thereby coinciding with the onset of Schwann cell DNA synthesis. At later times, however, further alterations in the sizes of the detected NRGlike species occur, suggesting that Schwann cells may be exposed to differentially spliced and/or processed NRG isoforms over the period studied in this work.

\section{Neuregulin induction is not detected in spinal cord and DRG postaxotomy}

The expression of NRG transcripts by cells within the nerve does not obviate the possibility that axon-associated NRG might contribute further to Schwann cell proliferation during regeneration. If NRGs are presented to Schwann cells on regenerating axonal growth cones, it is possible that an increase in NRG protein levels might be seen in the affected neuronal populations. Therefore, we examined the expression of NRG protein in lumbar (L4, L5, and L6) DRG and the lumbar enlargement of the spinal cord 0-30 d after surgical transection of the sciatic nerve using our panneuregulin antiserum. In contrast to axotomized nerve, analysis of protein expression in the lumbar DRG and spinal cord showed minimal evidence of neuregulin induction by sciatic nerve transection (Fig. 4A,B). Western blot studies of normal and postaxotomy DRG and spinal cord with the "secreted" (" 3 " juxtamembrane) and "a" neuregulin transmembrane precursors, as well as RNA (Northern blot, semiquantitative RT-PCR) analyses, also showed, at best, minimal evidence of alterations in neuregulin expression (data not shown). These results argue that if presentation of axon-associated NRG does play a role in regulating Schwann cell mitogenesis, it is not accompanied by a marked increase in the accumulation of neuronal NRG.

\section{Induction of Schwann cell DNA synthesis in axotomized sciatic nerve correlates with the onset of GGF induction}

Although the induction of Schwann cell DNA synthesis in surgically transected sciatic nerve has been carefully analyzed in the adult mouse (Bradley and Asbury, 1970) and cat (Pellegrino et al., 1986; Oaklander et al., 1987), a similar detailed analysis of postaxotomy Schwann cell mitotic indices in the rat has not been performed (Friede and Johnstone, 1967). Because it is well recognized that there are species-specific temporal variations in the onset and peak of Schwann cell mitogenesis (Lubinska, 1964), it was necessary that we establish these parameters for the rat. Crush or transection injury of the sciatic nerve was performed on three to five adult male Harlan Sprague Dawley rats per time point and, at the same times used for our RNA and protein isolations, animals were pulsed with BrdU to label cells in the DNA synthesis phase of the cell cycle. Labeled nuclei within the sciatic nerve distal to the side of axotomy were identified by immunohistochemistry, and the number of labeled cells seen in animals with crush injuries, which allows axonal regeneration, was compared with that seen in rats with transection injuries, in which axonal regrowth was prevented. Preliminary counts of labeled Schwann cell nuclei showed similar time courses of induction for DNA synthesis in crush and transection injuries (data not shown). Although virtually no BrdU incorporation was identified in noninjured nerve and $1 \mathrm{~d}$ postinjury, a marked increase in the number of labeled Schwann cell nuclei was evident at $3 \mathrm{~d}$ and reached a peak 5-7 d after injury (Fig. 5A-E). By $10 \mathrm{~d}$ postinjury, a decline in the number of Schwann cells synthesizing DNA was evident, and 18 and $30 \mathrm{~d}$ into the course of Wallerian degeneration, only scattered labeled nuclei were seen (Fig. $5 F$ ).

Although the largest number of labeled nuclei was found $5 \mathrm{~d}$ postaxotomy, it was not clear that this time represented the peak of mitotic activity, because the total number of Schwann cells also increases dramatically between 3 and $5 \mathrm{~d}$ after injury (Abercrombie and Johnson, 1946) (S.L.C., personal observations). Therefore, we determined the Schwann cell labeling index (number of labeled Schwann cell nuclei/total number of Schwann cell nuclei; for criteria used to identify Schwann cells, see Materials and Methods) in nerve 1,3 , and 5 d postaxotomy to establish the peak in mitotic activity. Because we had determined that neuregulin mRNA was persistently elevated through even the later phases of Wallerian degeneration, we also determined the Schwann cell labeling index $18 \mathrm{~d}$ postaxotomy. Studies were performed on serial sections from animals that had undergone surgical transection of the nerve with prevention of regeneration to avoid any complications that might be introduced by regenerating axon sprouts reentering more distal segments of the nerve. To detect any confounding variability that might be introduced by anterograde spread of mitotic activity, such as has been described in the cat (Oaklander et al., 1987), cell counts were performed at $3 \mathrm{~mm}$ intervals along the surgically transected nerve. Schwann cell labeling indices in noninjured nerve (Fig. 5G, Table 1), as well as the distal segment of nerve, $1 \mathrm{~d}$ postaxotomy (data not shown) were $<0.01 \%$. By $3 \mathrm{~d}$ postaxotomy, however, labeling indices throughout the nerve distal to the site of transection (excluding the distal stump) were $14-15 \%$ (Fig. 5G, Table 1). Schwann cell labeling indices obtained in distal nerve segments $5 \mathrm{~d}$ postaxotomy were lower (10-11\%; Fig. 5G, Table 1) than those determined $3 \mathrm{~d}$ 

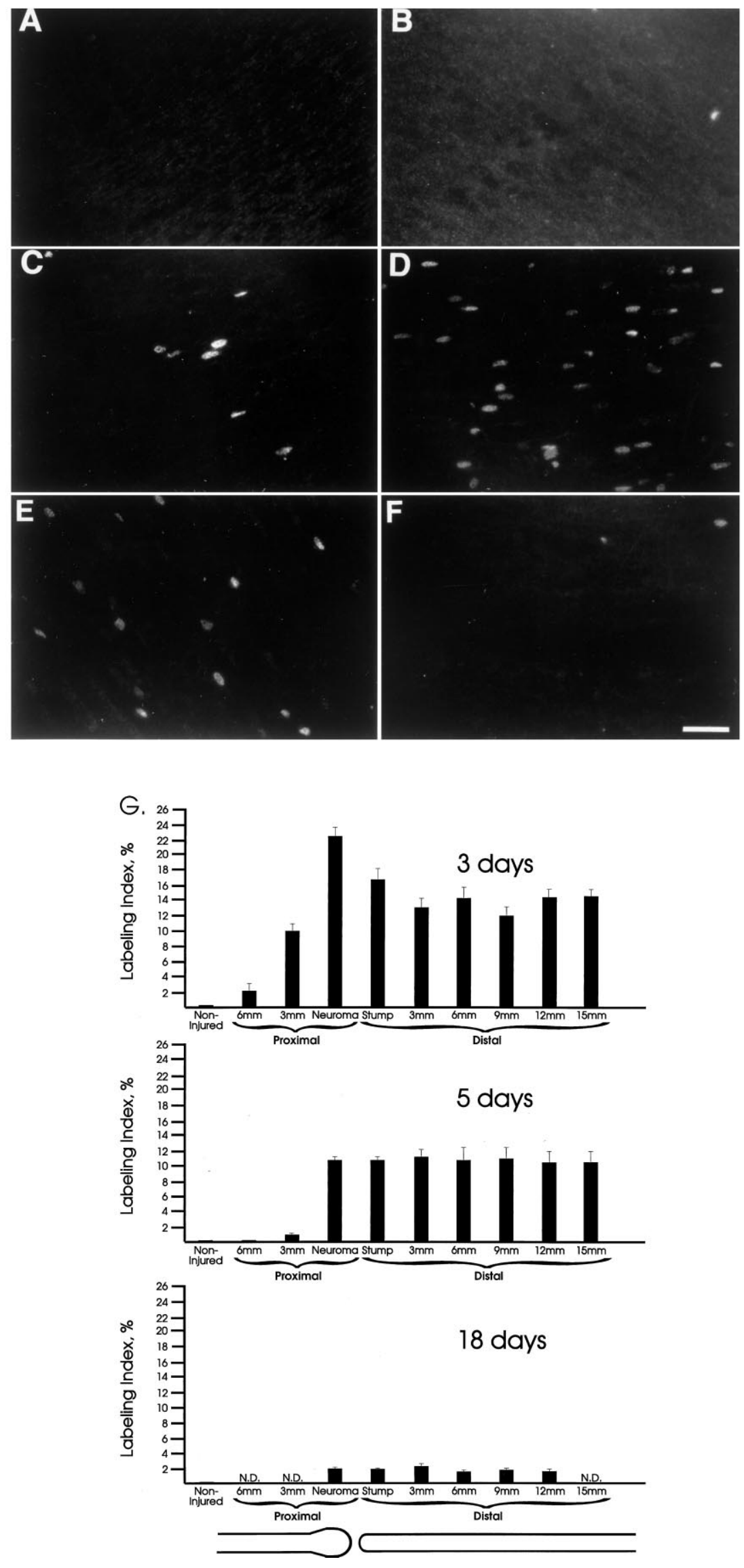

Figure 5. DNA synthesis by Schwann cells in axotomized sciatic nerve. $A-F$, Photomicrographs of BrdU-labeled Schwann cell nuclei in sciatic nerve crushed at the sciatic notch. Nuclei actively synthesizing DNA during the BrdU pulse were detected by silver-enhanced immunogold staining and visualized with epi-illumination. Shown are representative fields from noninjured nerve $(A)$ and nerve $15 \mathrm{~mm}$ distal to a site of crush injury $1 \mathrm{~d}(B), 3 \mathrm{~d}(C), 5 \mathrm{~d}$ $(D), 7 \mathrm{~d}(E)$, and $18 \mathrm{~d}(F)$ after injury. All photomicrographs are taken at $400 \times$ magnification. Scale bar, $50 \mu \mathrm{m}$. $G$, Schwann cell labeling indices 3, 5, and $18 \mathrm{~d}$ after surgical transection. Mean labeling indices \pm SEs are indicated by the horizontal bars. Positions relative to the site of injury are indicated below each bar, as well as by the schematic diagram at the bottom of the figure. N.D., Not done. 


\begin{tabular}{|c|c|c|c|c|c|}
\hline Time postaxotomy & Position & $\begin{array}{l}\text { No. of sections } \\
\text { examined }\end{array}$ & $\begin{array}{l}\text { No. of Schwann cell } \\
\text { nuclei labeled/examined }\end{array}$ & $\begin{array}{l}\text { Average } \\
\text { labeling index }\end{array}$ & $\mathrm{SE}$ \\
\hline \multirow[t]{10}{*}{$3 \mathrm{~d}$} & Noninjured & 28 & $2 / 706$ & $0.16 \%$ & $0.15 \%$ \\
\hline & $6 \mathrm{~mm}$ proximal & 30 & $9 / 468$ & $2.3 \%$ & $1.1 \%$ \\
\hline & $3 \mathrm{~mm}$ proximal & 30 & $54 / 920$ & $10.0 \%$ & $0.9 \%$ \\
\hline & Neuroma & 18 & $431 / 1980$ & $22.2 \%$ & $1.3 \%$ \\
\hline & Stump & 32 & $329 / 2134$ & $16.6 \%$ & $1.7 \%$ \\
\hline & $3 \mathrm{~mm}$ distal & 26 & $89 / 718$ & $13.1 \%$ & $1.5 \%$ \\
\hline & $6 \mathrm{~mm}$ distal & 30 & $107 / 796$ & $14.6 \%$ & $1.7 \%$ \\
\hline & $9 \mathrm{~mm}$ distal & 20 & $55 / 477$ & $11.9 \%$ & $1.3 \%$ \\
\hline & $12 \mathrm{~mm}$ distal & 16 & $59 / 417$ & $14.4 \%$ & $1.2 \%$ \\
\hline & $15 \mathrm{~mm}$ distal & 12 & $50 / 353$ & $14.5 \%$ & $1.1 \%$ \\
\hline \multirow[t]{10}{*}{$5 \mathrm{~d}$} & Noninjured & 24 & $0 / 670$ & 0 & 0 \\
\hline & $6 \mathrm{~mm}$ proximal & 4 & $0 / 117$ & 0 & 0 \\
\hline & $3 \mathrm{~mm}$ proximal & 22 & $6 / 595$ & $0.9 \%$ & $0.3 \%$ \\
\hline & Neuroma & 34 & $257 / 2479$ & $10.5 \%$ & $0.7 \%$ \\
\hline & Stump & 28 & $224 / 2146$ & $10.5 \%$ & $0.5 \%$ \\
\hline & $3 \mathrm{~mm}$ distal & 18 & $76 / 699$ & $11.1 \%$ & $1.3 \%$ \\
\hline & $6 \mathrm{~mm}$ distal & 22 & $69 / 794$ & $10.4 \%$ & $2.0 \%$ \\
\hline & $9 \mathrm{~mm}$ distal & 30 & $98 / 966$ & $10.7 \%$ & $1.4 \%$ \\
\hline & $12 \mathrm{~mm}$ distal & 20 & $82 / 795$ & $10.2 \%$ & $1.5 \%$ \\
\hline & $15 \mathrm{~mm}$ distal & 6 & $20 / 243$ & $8.1 \%$ & $1.4 \%$ \\
\hline \multirow[t]{10}{*}{$18 \mathrm{~d}$} & Noninjured & 12 & $1 / 910$ & $0.1 \%$ & $0.1 \%$ \\
\hline & $6 \mathrm{~mm}$ proximal & ND & & & \\
\hline & $3 \mathrm{~mm}$ proximal & ND & & & \\
\hline & Neuroma & 34 & $117 / 6652$ & $1.9 \%$ & $0.2 \%$ \\
\hline & Stump & 36 & $82 / 4080$ & $1.9 \%$ & $0.2 \%$ \\
\hline & $3 \mathrm{~mm}$ distal & 28 & $61 / 3006$ & $2.3 \%$ & $0.5 \%$ \\
\hline & $6 \mathrm{~mm}$ distal & 28 & $43 / 2779$ & $1.6 \%$ & $0.2 \%$ \\
\hline & $9 \mathrm{~mm}$ distal & 36 & $52 / 3193$ & $1.8 \%$ & $0.3 \%$ \\
\hline & $12 \mathrm{~mm}$ distal & 34 & $50 / 3651$ & $1.4 \%$ & $0.3 \%$ \\
\hline & $15 \mathrm{~mm}$ distal & ND & & & \\
\hline
\end{tabular}

ND, Not determined.

postaxotomy. Mitotic activity is markedly lower by $18 \mathrm{~d}$ postaxotomy with a labeling index of $\sim 2 \%$ seen throughout the distal segment of the nerve (Fig. $5 G$, Table 1 ). We conclude that the peak of Schwann cell mitotic activity occurs $3 \mathrm{~d}$ postaxotomy, a result similar to that obtained previously with explants of degenerating rat nerve maintained in vitro (Clemence et al., 1989). The onset of Schwann cell proliferation therefore coincides with the initial induction of neuregulin mRNA synthesis. In the later phases of Wallerian degeneration (18 and $30 \mathrm{~d}$ postaxotomy), although elevated levels of neuregulin mRNA are still present, Schwann cell mitotic activity is markedly decreased.

\section{The erbB2 and erbB3 neuregulin receptors are coordinately induced by axotomy of peripheral nerve}

Although neuregulin expression is clearly induced in sciatic nerve by axotomy and coincides with the onset of Schwann cell DNA synthesis, it remained to be determined whether Schwann cells bear the erbB receptors necessary for responsiveness to neuregulins in vivo. The erbB family of receptors consists of four genes in man known as erbB1 (the EGF receptor), erbB2 (HER2/c-neu), erbB3 (HER3), and erbB4 (HER4/tyro2) (for review, see Peles and Yarden, 1993; Ben-Baruch and Yarden, 1994). Although the human (Xu et al., 1984; Haley et al., 1987), mouse (Avivi et al.,
1991; Luetteke et al., 1994), and chicken (Flickinger et al., 1992) EGF receptor genes have been cloned, and erbB2 has been cloned from several species, including the rat (Bargmann et al., 1986), only human $e r b B 3$ and $e r b B 4$ receptor cDNAs had been isolated when we began this work (Plowman et al., 1990, 1993). Therefore, we used RT-PCR with axotomized sciatic nerve, DRG and spinal cord templates to isolate partial cDNAs of the rat EGF, erbB3, and $e r b B 4$ receptors, and sequenced these clones to establish their relationship to the human genes. Each of the rat clones was found to be closely related to their human and (when sequence was available) mouse orthologs (Luetteke et al., 1994; Moscoso et al., 1995). The rat $e r b B 3$ and $e r b B 4$ clones were used to screen the nerve and spinal cord libraries. More extensive cDNAs were isolated for each receptor and characterized for use in our studies (see Materials and Methods).

Although all NRG splice variants share the common characteristic of stimulating erbB2 tyrosine phosphorylation, it has become evident that the products of the closely related proto-oncogenes $e r b B 3$ and $e r b B 4$ are the specific receptors for the NRGs and that erbB2 transphosphorylation occurs when ligand binding induces erbB3 or erbB4 to form a heterodimer with erbB2 (Carraway and Cantley, 1994). It has been demonstrated previously that the 


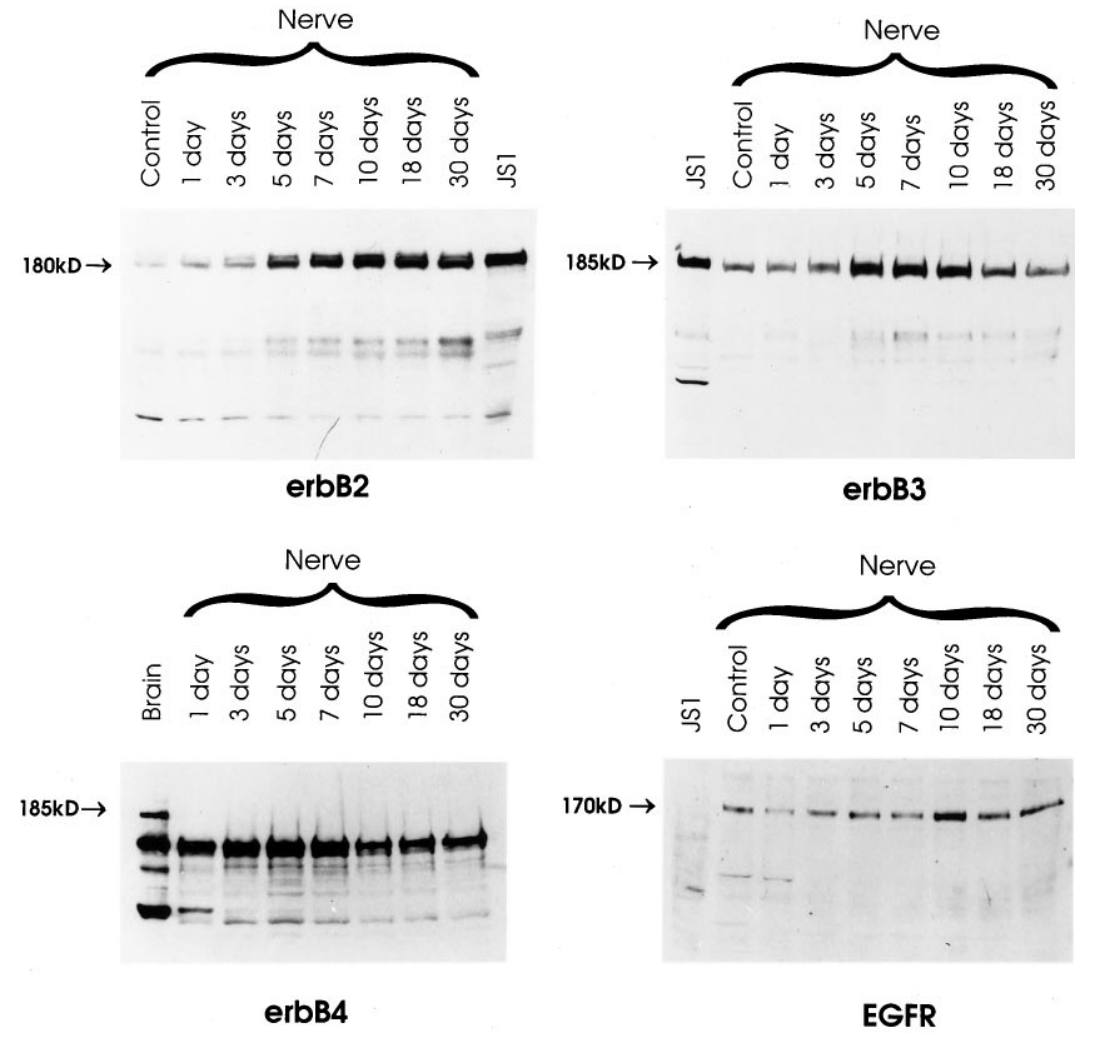

Figure 6. erbB2 and erbB3 are coordinately induced in sciatic nerve by surgical transection. Western blots of tissue lysates prepared from noninjured (Control) and the segment of sciatic nerve distal to a site of surgical transection (1-30 d postaxotomy), as well as whole-cell lysates of JS1 cells, were probed with antibodies specific for each of the erbB membrane tyrosine kinases (indicated below each panel). Although erbB1 (EGF receptor), erbB2, and erbB3 are readily detectable in sciatic nerve, erbB4 was never seen in axotomized nerve over this time course (note the easily visualized band in the brain lysate). Western blot analyses were also used to confirm that erbB4 was absent in noninjured nerve and JS1 cells (data not shown).
erbB2 receptor is expressed by Schwann cells (Cohen et al., 1992; Jin et al., 1993). To determine whether erbB3 or erbB4 receptors are expressed in sciatic nerve, RNA from noninjured and postaxotomy nerve, the JS1 schwannoma cell line, and other nervous system structures were probed for expression of the corresponding mRNAs. Although erbB4 was undetectable in both noninjured and surgically transected nerve, erbB3 mRNA was readily detectable in noninjured sciatic nerve and was induced six- to sevenfold by $7 \mathrm{~d}$ postaxotomy (data not shown). Furthermore, very high levels of erbB3 mRNA were present in the JS1 schwannoma line, suggesting that Schwann cells might be the source of erbB3 mRNA in peripheral nerve.

The effects of sciatic axotomy on the expression of all four erbB receptors were examined by probing immunoblots of lysates from noninjured nerve and the segment of nerve distal to a site of surgical transection over the same period examined for neuregulin expression. Although erbB4 was undetectable at all time points examined, erbB1, erbB2, and erbB3 proteins were present in sciatic nerve at all time points studied (Fig. 6). The erbB2 receptor protein is upregulated in response to sciatic axotomy beginning $5 \mathrm{~d}$ postaxotomy, in keeping with previous observations at the mRNA level (Cohen et al., 1992). Intriguingly, we also found that the erbB3 receptor is induced with a time course parallel to that of erbB2. The expression of both erbB2 and erbB3 persists at an elevated level until $18 \mathrm{~d}$ postaxotomy, when a slight decline is evident for both receptors (more so for erbB3 than erbB2). EGF receptor is also induced by axotomy, peaking at $10 \mathrm{~d}$ after transection. However, it is interesting that although both erbB2 and erbB3 are present at high levels in the JS1 schwannoma cell line, the EGF receptor is undetectable in this cell line. This result, coupled with preliminary immunohistochemical studies showing that the most intense EGF receptor immunoreactivity in axotomized nerve is associated with epineurial cells (S.S.K. and S.L.C., unpublished observations), suggests that a cell type(s) other than Schwann cells may be the source of much of the EGF receptor protein in nerve.

\section{Immunoreactive neuregulin and erbB protein in normal and postaxotomy nerve localizes to Schwann cells}

Although our analyses of neuregulin and erbB receptor mRNA and protein in sciatic nerve clearly demonstrated that increased expression of these molecules is induced by axotomy, their cellular source remained unclear. Therefore, we localized neuregulin-, erbB2-, and erbB3-like immunoreactivity in noninjured sciatic nerve and nerve segments distal to a site of surgical transection 3 , 5 , and $7 \mathrm{~d}$ postaxotomy. To assess possible cellular associations of these molecules, Schwann cells and axons were identified in these preparations by staining with antibodies for $\mathrm{S} 100 \beta$ and neurofilaments (SMI 34, a mouse monoclonal recognizing heavily phosphorylated $\mathrm{H}$ and $\mathrm{M}$ chains found in peripheral axons), respectively. Three different antibodies to different neuregulin epitopes were used in these studies and found to give identical immunohistochemical results (see below).

An initial characterization verified that the pan-neuregulin antiserum reproduced previously described patterns of staining in skeletal muscle and dorsal root ganglia (see Materials and Methods). These antibodies were found to label both noninjured and axotomized nerve. In noninjured nerve, immunoreactivity was visualized as fluorescent streaks. Double-label indirect immunofluorescence demonstrated that the panneuregulin immunoreactivity was associated with Schwann cells (Fig. $7 A, B$ ) and did not overlap with that for neurofilaments (Fig. $7 C$ ). The absence of axonal neuregulin immunoreactivity in the more proximal segments of noninjured nerve is consistent with previous reports (Sandrock et al., 1995). The panneuregulin antiserum also diffusely labeled the cytoplasm and 

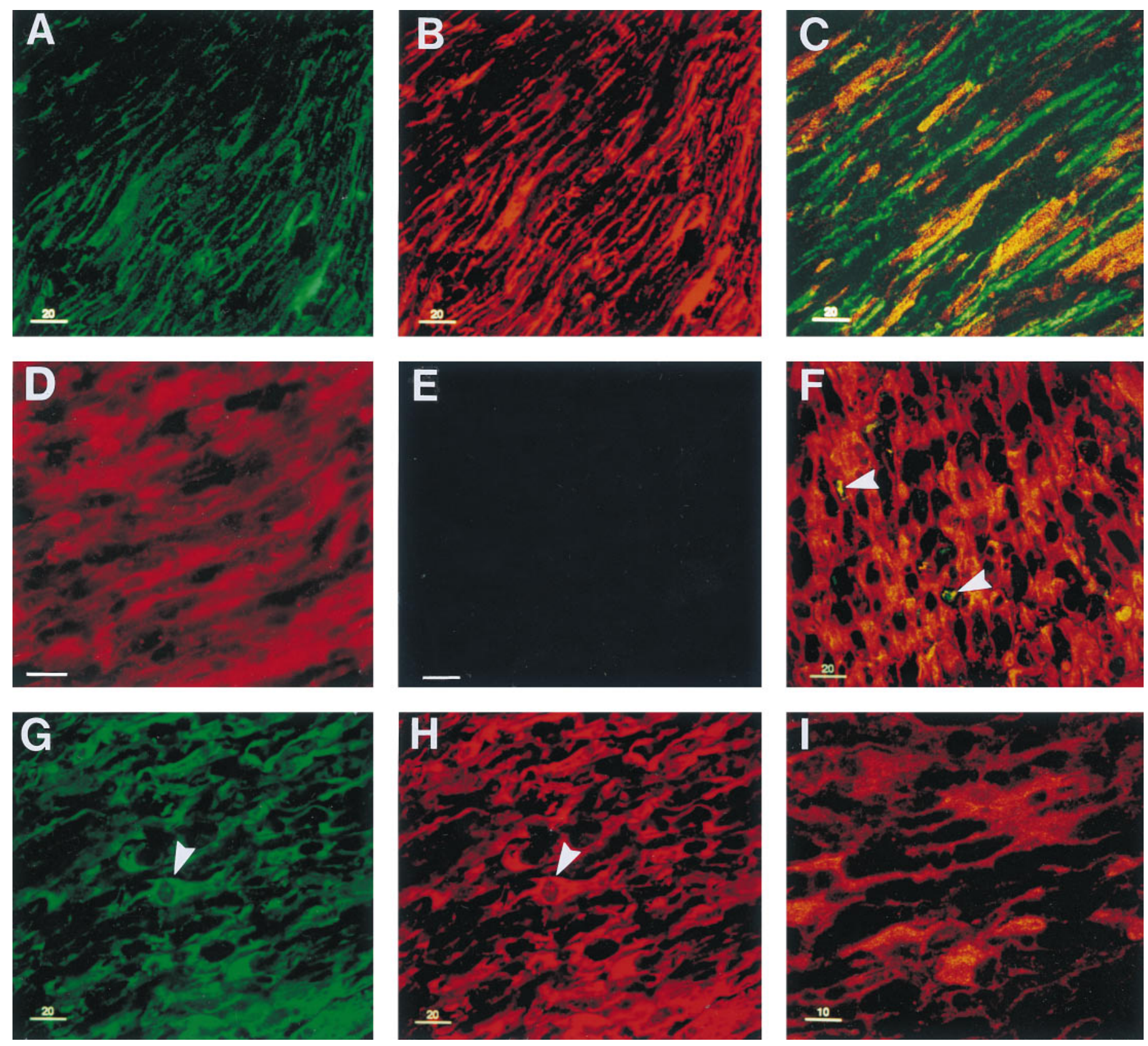

Figure 7. Neuregulin-like immunoreactivity in normal and surgically transected sciatic nerve visualized by indirect immunofluorescence. $A-C$, Confocal images of longitudinal sections of noninjured sciatic nerve double-labeled with the pan-neuregulin antiserum [DTAF ( green) label in $A$ and Cy3 label (orange-red) in $C]$ and antibodies to either the Schwann cell marker $\mathrm{S} 100 \beta$ [B; rhodamine (orange-red)-labeled cells] or neurofilaments [C; DTAF ( green)-labeled structures]. Note the virtually identical pattern of pan-neuregulin and $\mathrm{S} 100 \beta$ staining (compare $A$ and $B$ ); the orange Cy3 staining seen in $C$ is a consequence of adjusting the staining intensities to similar levels and does not reflect colocalization of labels. In contrast, there is virtually no overlap in pan-neuregulin and neurofilament immunoreactivity, a pattern of staining identical to that seen in control double-label immunohistochemistry experiments using anti-S100 $\beta$ and -neurofilament antibodies (data not shown). Scale bars, $20 \mu \mathrm{m} . D, E$, Conventional immunofluorescence photographs of longitudinal sections from the distal stump of sciatic nerve $3 \mathrm{~d}$ post-transection stained with pan-neuregulin antiserum preincubated with either a nonrelated peptide $(D)$ or the immunizing peptide $(E)$. Staining with the pan-neuregulin antiserum labels both the cytoplasm and membranes of Schwann cells; note that this staining is eliminated by preincubation with the immunizing peptide. Scale bars, $25 \mu \mathrm{m}$. F, Confocal image of sciatic nerve $7 \mathrm{~d}$ postaxotomy double-labeled with the pan-neuregulin antiserum [Cy3 label (orange-red)] and neurofilament antibody [DTAF label ( green)]. Although cytoplasmic and membranous staining for neuregulin is widespread, only rare axonal remnants within myelin digestion chambers stain for neurofilaments (arrows). Scale bar, $20 \mu \mathrm{m}$. $\mathrm{G}, \mathrm{H}$, Confocal images of sciatic nerve $5 \mathrm{~d}$ postaxotomy stained with the pan-neuregulin antibodies [DTAF label (green)] and the Schwann cell marker S100 $\beta$ [rhodamine label (orange-red)]. Note the cell (arrow) in the center of each field, which demonstrates immunoreactivity for each antigen. Scale bars, $20 \mu \mathrm{m}$. I, Confocal image of sciatic nerve $5 \mathrm{~d}$ postaxotomy immunostained with antibody directed against neuregulin transmembrane precursors with an "a" C terminus [Cy3 (orange-red) label]. Scale bar, $10 \mu \mathrm{m}$.

cellular membranes of the majority of cells in the endoneurium of axotomized nerve 3,5 , and $7 \mathrm{~d}$ postaxotomy, with the intensity and distribution of staining increasing over this period. In both normal and axotomized nerve, antibody staining was not observed in the absence of primary antibody (data not shown) and was specifically blocked by preincubation with the immunizing peptide (compare the staining seen in the $3 \mathrm{~d}$ postaxotomy nerve in Fig. $7 D$ with that in Fig. $7 E$, in which the 

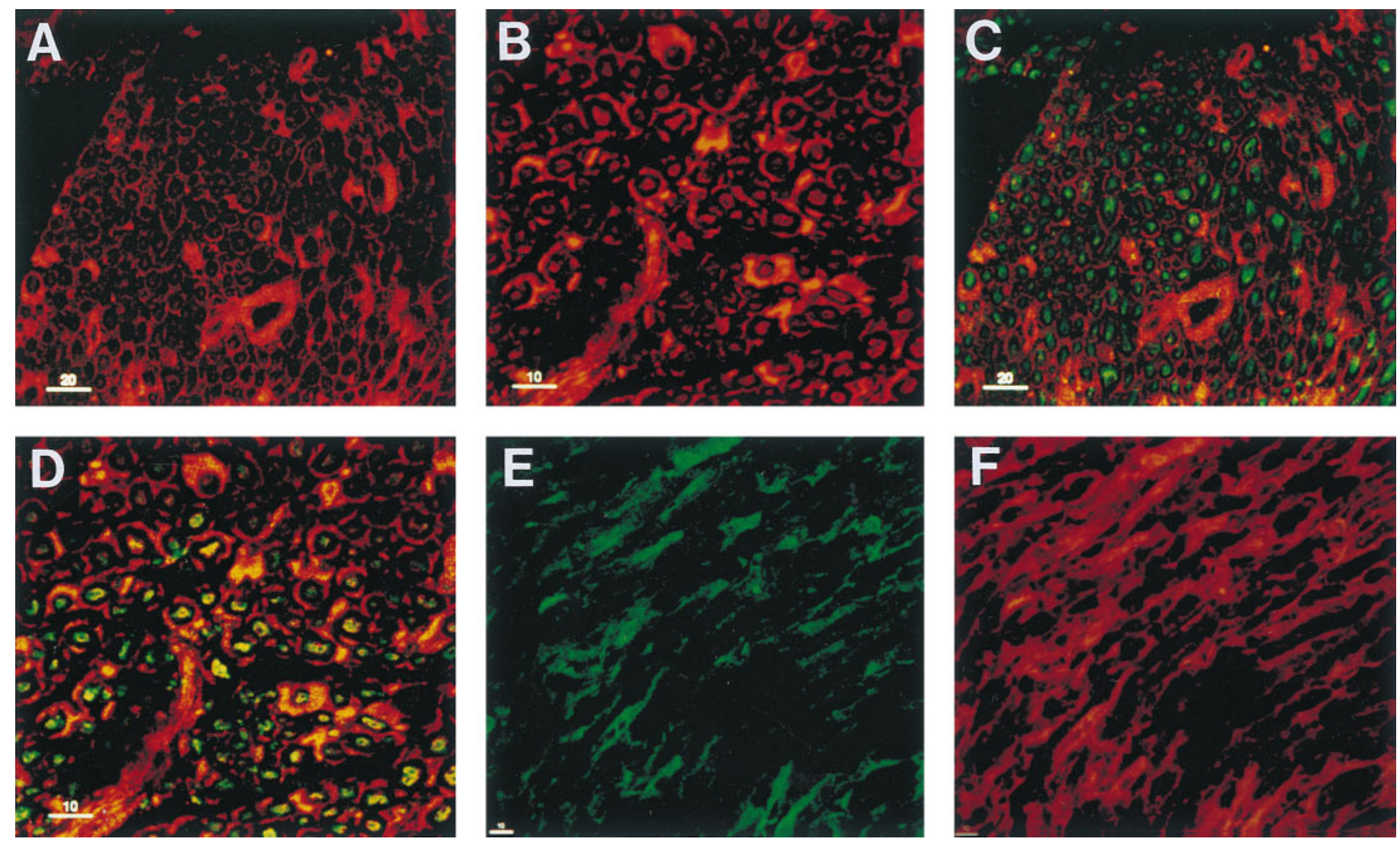

Figure 8. Indirect immunofluorescent localization of erbB2 and erbB3 in normal and surgically transected sciatic nerve. $A$, $B$, Confocal images of cross sections of noninjured nerve decorated with antibody to erbB2 $(A)$ or erbB3 $(B)$. Staining is visualized as rings of orange-red staining surrounding a region of central staining. Scale bars: $20 \mu \mathrm{m}$ in $A$ and $10 \mu \mathrm{m}$ in $B$. $C, D$, Confocal images of cross sections of noninjured nerve double-labeled with antibody to neurofilament [DTAF ( green) label] and either erbB2 $(C)$ or erbB3 [D; erbB antibodies visualized with Cy3-labeled secondary antibodies (orange-red)]. Note the unstained region separating the outer rings of erbB receptor immunostaining from the central axonal (neurofilament) staining. As a control, double-label immunohistochemistry for S100 $\beta$ and neurofilament was also performed on adjacent sections of normal nerve. $\mathrm{S} 100 \beta$ staining produced rings of staining highly similar to those seen with the erbB antibodies, but lacked the central staining; S100 $\beta$ immunoreactivity showed no overlap with neurofilament staining (data not shown). Scale bars: $20 \mu \mathrm{m}$ in $C$ and $10 \mu \mathrm{m}$ in $D$. $E, F$, Confocal image of a longitudinal section of sciatic nerve $5 \mathrm{~d}$ postaxotomy stained with antibody directed against erbB3 [DTAF (green) label] and the Schwann cell marker S100 $\beta$ [rhodamine (orange-red) label]. Diffuse staining of cells in the endoneurium is seen with the erbB3 antibody $(E)$. This pattern overlaps completely with the distribution of the $\mathrm{S} 100 \beta$ marker $(F)$. The nonstaining spaces seen in $F$ correspond to myelin digestion chambers when visualized by Nomarski optics (data not shown). In keeping with an earlier report (Cohen et al., 1992), an essentially identical distribution of erbB2 immunoreactivity was seen (data not shown). Scale bars, $10 \mu \mathrm{m}$.

antiserum has been preincubated with the immunizing peptide). Dual labeling with the pan-neuregulin antiserum and neurofilament antibodies demonstrated that the axons had largely deteriorated by 5 and $7 \mathrm{~d}$ postaxotomy and that the neurofilament staining pattern did not overlap with immunoreactive neuregulin (Fig. $7 F$ ). In contrast, double-labeling experiments with the pan-neuregulin antiserum and antibodies to S100 $\beta$, a Schwann cell marker, showed complete overlap of the staining pattern of these two antibodies (Fig. $7 G, H$ ). The staining pattern of the pan-neuregulin antiserum in normal and axotomized nerve was also compared with that seen with antibodies to different neuregulin epitopes (the $\mathrm{C}$ termini of neuregulin splice variants with " 3 " juxtamembrane domains and transmembrane precursors with "a" C termini). Both of these antibodies showed a distribution of staining in the endoneurium similar to that seen with the pan-neuregulin antiserum, with the " 3 " antibody producing diffuse cytoplasmic staining and the "a" C terminus antibody detecting a membrane-associated and, to a lesser extent, cytoplasmic antigen. It is particularly notable that immunoreactivity for neu- regulin transmembrane precursors is associated with Schwann cells (Fig. 7I), because the epitope recognized by this antibody is not thought to be released from the cell of origin when the precursor is proteolytically processed (Wen et al., 1994). We conclude that the neuregulin-like immunoreactivity in axotomized sciatic nerve is associated with Schwann cells and that the demonstration of immunoreactivity for neuregulin transmembrane precursors, considered in conjunction with the data described above, suggests that Schwann cells are a major source of neuregulin mRNA and protein in this tissue.

If the erbB2 and erbB3 receptors mediate the Schwann cell response to axon-associated neuregulin, it is expected that these molecules would be expressed on the Schwann cell membrane facing the axon to facilitate reception of the neuronal signal. We therefore immunolocalized erbB protein on crosssections of noninjured nerve and examined its relationship to the axon, as highlighted by staining for neurofilaments. Both erbB2 and erbB3 were readily detectable in this tissue with a virtually identical distribution. Immunoreactivity for erbB receptors was detected as intense rings of immunofluorescence 
with fainter central staining (Fig. $8 A, B$ ). No staining was observed in the absence of primary antibodies, and preincubation of the primary antisera with the immunizing peptides completely blocked immunostaining, whereas preincubation with a nonrelated peptide had no effect (data not shown). Colocalization with immunoreactivity for neurofilaments demonstrated that the outer rim of erbB2 and erbB3 staining was separated from the axon by an unstained region, presumably representing the myelin sheath of the Schwann cell (Fig. 8C,D); this rim of erbB receptor staining completely overlapped that of $\mathrm{S} 100 \beta$ (data not shown). In contrast, the central erbB2 and erbB3 staining colocalized with neurofilament immunoreactivity, suggesting that these erbB-like proteins are axon-associated. The simplest interpretation is that a major portion of the immunoreactive erbB2 and erbB3 protein is on the outer surface of the Schwann cell adjacent to the basement membrane. We would caution, however, that some of the erbB2 and erbB3 receptors may be on the inner face of the Schwann cell, because the weaker staining seen centrally with these antibodies may represent a combination of axonal and Schwann cell staining. More precise localization using techniques such as immunoelectron microscopy will be required to resolve this issue.

To establish that the increase in erbB2 and erbB3 protein observed beginning $5 \mathrm{~d}$ postaxotomy resulted from increased Schwann cell expression of these molecules, we also examined erbB receptor immunoreactivity in axotomized sciatic nerve (3, 5 , and $7 \mathrm{~d}$ postaxotomy). The majority of cells in the endoneurium stained with an essentially identical pattern for both erbB2 and erbB3, with the most intense staining seen 5 and $7 \mathrm{~d}$ postaxotomy (Fig. $8 E$ ). In keeping with earlier descriptions of erbB2 immunostaining in axotomized nerve (Cohen et al., 1992), both erbB2 and erbB3 antibodies produced cytoplasmic and cell surface staining of endoneurial elements. Colocalization with the Schwann cell marker $\mathrm{S} 100 \beta$ demonstrated a complete overlap between staining for $\mathrm{S} 100 \beta$ and the erbB2 and erbB3 receptors (Fig. $8 F$ ). We conclude that most, if not all, immunoreactive erbB2 and erbB3 protein in axotomized peripheral nerve is specifically associated with Schwann cells and that these cells are thus potentially responsive to neuregulins in vivo.

\section{DISCUSSION}

The neuregulins have been demonstrated to be potent Schwann cell mitogens in vitro (Brockes et al., 1980; Goodearl et al., 1993; Levi et al., 1995) and are proposed to function as growth and differentiation factors mediating axon-Schwann cell interactions during the normal development of the peripheral nervous system (Shah et al., 1994; Morrissey et al., 1995; Trachtenberg and Thompson, 1996). Therefore, it is reasonable to postulate that NRGs, possibly liberated from the injured axon, initiate Schwann cell proliferation during Wallerian degeneration of adult peripheral nerve. We have found that the GGF subfamily of neuregulins and their erbB2 and erbB3 receptors are expressed in a pattern expected for postaxotomy mediators of Schwann cell mitogenesis. However, our original hypothesis requires modification to accommodate several unexpected observations. First, expression of GGF mRNA is induced within surgically transected sciatic nerve, and immunoreactive neuregulin (including transmembrane precursors) is specifically associated with Schwann cells, suggesting that NRGs mediate autocrine or paracrine interactions between cells endogenous to nerve rather than acting solely as an axon-derived signal. Second, although GGF mRNA induction coincides with the initiation of Schwann cell DNA synthesis, it lasts throughout a subsequent period of markedly diminished Schwann cell mitogenesis, raising the questions of whether Schwann cells have a mechanism for shutting off mitosis in the presence of persistent GGF and whether the NRGs play additional roles in the response to nerve injury. Third, the erbB2 and erbB3 receptors are coordinately induced in the Schwann cells of axotomized nerve, suggesting that the density of functional GGF receptors may modulate GGF actions during Wallerian degeneration.

The onset of Schwann cell DNA synthesis in surgically transected sciatic nerve $3 \mathrm{~d}$ postaxotomy coincides with the initial accumulation of NRG mRNAs and at least some forms of NRG protein. NRG mRNA is undetectable in noninjured nerve by RNA blot analysis, with significant accumulation beginning $3 \mathrm{~d}$ after the axon is separated from the cell body and persisting to $30 \mathrm{~d}$ postaxotomy, a time well after the axon has degenerated and been phagocytosed. Furthermore, our RT-PCR analyses indicate that the neuregulin EGF-like/juxtamembrane domains expressed in sciatic nerve differ significantly from those seen in the lumbar DRG and spinal cord. We conclude that NRG mRNAs induced in response to peripheral nerve injury are derived from cells within the nerve itself. Potential cellular sources of NRG mRNAs in axotomized nerve include fibroblasts, perineurial cells, Schwann cells, mast cells, and macrophages. In keeping with an earlier report that schwannomas express extremely high levels of a GGFlike activity (Brockes et al., 1986), we have found that the JS1 schwannoma cell line synthesizes very high levels of NRG mRNAs, thereby demonstrating that Schwann cells are capable of synthesizing NRGs under at least some circumstances (neoplasia). Furthermore, we have demonstrated that immunoreactive neuregulins, including transmembrane precursors, are specifically associated with Schwann cells. The elaboration of NRG mRNAs by cells endogenous to the injured nerve, combined with the findings that a clonal Schwann cell line produces NRGs and that Schwann cells within nerve undergoing Wallerian degeneration stain for NRG-like proteins (including transmembrane precursors), argues that Schwann cells themselves express NRGs postaxotomy and thereby may drive Schwann cell mitogenesis either through the activation of an autocrine loop or via paracrine effects on their neighbors.

There is strong evidence that axon-associated neuregulins promote Schwann cell differentiation and proliferation in the developing peripheral nervous system (Shah et al., 1994; Dong et al., 1995; Lee et al., 1995; Marchionni, 1995; Morrissey et al., 1995; Trachtenberg and Thompson, 1996). This raises the question of whether axon-associated neuregulins also play a role in Schwann cell proliferation in axotomized adult nerve. We and others (Goodearl et al., 1995) have not detected NRG immunoreactivity in more proximal axonal segments in noninjured nerve. However, there is evidence that NRGs synthesized in the neuronal cell body are transported to the most distal portions of the axon (Goodearl et al., 1995; Jo et al., 1995; Moscoso et al., 1995; Sandrock et al., 1995). This suggests that levels of NRG protein that are below the limits of detection immunohistochemically may be present in the more proximal segments of noninjured axons. Because of the current uncertainty regarding the NRG concentrations required for an in vivo biological response, we would therefore caution that a role for axon-associated NRGs, particularly in the early stages of Wallerian degeneration, cannot be discarded. It is conceivable that Schwann cells may be initially influenced by $\beta$ NRGs liberated 
from the degenerating axon, with subsequent proliferation and/or other effects (see below) mediated by $\alpha$ - and/or $\beta$ NRGs produced by the Schwann cells themselves. This potential for dual sources of NRG is reminiscent of recent observations in skeletal muscle that suggest that erbB receptors at the neuromuscular synapse may be activated either by $\beta$ NRG secreted by peripheral nerve or a mixture of $\alpha$ - and $\beta$ NRGs produced by the muscle fiber itself (Moscoso et al., 1995).

One of our more surprising results was the finding that elevated neuregulin mRNA and protein levels persist for as long as $30 \mathrm{~d}$ postaxotomy, a time well after the Schwann cell labeling index has decreased to a small fraction of its peak value. Precisely how a decrease in Schwann cell mitogenesis is accomplished in the face of continued elevated levels of NRGs is currently unclear. Possibilities include a compartmentalization of NRGs that precludes interaction with the Schwann cell erbB receptors, an acquired resistance (desensitization) to NRG stimulation after the initial period of mitogenesis, and a predominance of other NRG actions (e.g., maintenance of a new state of differentiation, prevention of apoptotic death after separation from axons) in the later phases of Wallerian degeneration. We would also caution that it is possible that the neuregulins produced by Schwann cells may have actions on other cell types within injured nerve. At least some of these effects could potentially be modulated by varying the types of neuregulin splice variants expressed over the first $30 \mathrm{~d}$ of Wallerian degeneration. It will therefore be of great interest to analyze in detail the structure of the neuregulin isoforms expressed in sciatic nerve over the course of the events we have defined in this work.

In contrast to the mesenchymal neuregulin isoforms (Wen et al., 1994), the SMDF and GGF neuregulin splice variants have not been studied extensively. Only truncated and presumably secreted ( $\beta 3)$ splice variants have been described previously for GGF (Marchionni et al., 1993) and SMDF (Ho et al., 1995). Based on the cDNAs described in this work, we now know that transmembrane forms exist for both of these NRG subfamilies. Furthermore, our detection of solely GGF mRNAs in axotomized nerve, combined with the extensive splice variability of the EGF-like/ juxtamembrane domains identified in this same tissue by RTPCR, suggests that many more GGF isoforms remain to be described, including GGF $\alpha$ splice variants. The presence of $\mathrm{NRG} \alpha$ isoforms in axotomized nerve is of particular interest, because earlier work in some systems (Marikovsky et al., 1995), including Schwann cell precursors (Dong et al., 1995), suggests that NRG $\alpha$ splice variants may not be mitogenic. However, the potential mitogenic action of NRG $\alpha$ isoforms may be dependent on the combination of erbB receptors expressed by the target cell (Pinkas-Kramarski et al., 1996). Because Schwann cell precursors, unlike adult Schwann cells, express the erbB4 receptor (Dong et al., 1995), the responses of these two cell types to $\alpha$ NRGs may not be equivalent. Careful examination of the actions of $\alpha$ NRGs on adult Schwann cells will be required to resolve this issue.

A transition between different neuregulin receptor subtypes is yet another potential mechanism for modulating NRG actions during Wallerian degeneration of peripheral nerve. However, our demonstration that only erbB2 and erbB3 receptors are expressed in noninjured nerve and throughout the entire period of Wallerian degeneration that we studied argues that an erbB2/erbB3 heterodimer most likely represents the functional neuregulin receptor in Schwann cells and is consistent with an earlier report that these receptors are expressed by cultured human Schwann cells (Levi et al., 1995). We have found no evidence of erbB4 mRNA or protein in noninjured or axotomized rat sciatic nerve by in situ hybridization (M.L.M. and S.L.C., unpublished observations), RNA blot analysis, ribonuclease protection assay, or immunoblotting. Our data therefore indicate that erbB4 is not expressed by Schwann cells during our period of study and argues that any potential modulation of neuregulin actions in the later phases of Wallerian degeneration is unlikely to be attributable to a transition between erbB3 and erbB4 receptors and resultant remodeling of the signaling complex. In contrast to a transition between neuregulin receptor subtypes, however, variation in the density of the erbB2 and erbB3 Schwann cell receptors may play an important role in modulating neuregulin actions during Wallerian degeneration of peripheral nerve, because these two receptors are apparently coordinately upregulated in Schwann cells beginning $5 \mathrm{~d}$ postaxotomy. Because the number of Schwann cells in nerve also increases postaxotomy, validation of this hypothesis will require an assessment of the number of erbB2/erbB3 receptors per Schwann cell in noninjured nerve and postaxotomy.

Analysis of neuregulin and erbB receptor expression in peripheral nerve undergoing Wallerian degeneration has provided several new insights that have modified our view of this complex and intriguing process. In addition to identifying previously unexpected routes of interaction for the neuregulins, our analyses have also allowed us to narrow the field of candidate molecules that must be manipulated in the next stage of this work, i.e., interrupting signaling through the Schwann cell neuregulin/erbB pathway to establish whether activation of this pathway is required for Schwann cell mitogenesis after axotomy. Although mice with genetic ablation of the neuregulin (Meyer and Birchmeier, 1995), erbB2 (Lee et al., 1995), and erbB4 (Gassman et al., 1995) genes have been derived, they die in utero (embryonic days 10-11) at a period before the development of Schwann cells (Jessen and Mirsky, 1991; Jessen et al., 1994). Future progress, therefore, will depend on the development of alternative means of interrupting the neuregulin/erbB signaling pathways in proliferating adult Schwann cells.

\section{REFERENCES}

Abercrombie M, Johnson ML (1946) Quantitative histology of Wallerian degeneration. I. Nuclear populations in rabbit sciatic nerve. J Anat 80:37-50.

Aguayo A, Samuel D, Richardson P, Bray G (1978) Axon elongation in peripheral and central nervous system transplants. Adv Cell Neurobiol 3:215-234.

Avivi A, Lax I, Ullrich A, Schlessinger J, Givol D, Morse B (1991) Comparison of EGF receptor sequences as a guide to study the ligand binding site. Oncogene 6:673-676.

Bandtlow CE (1993) Axonal regeneration in the adult vertebrate CNS. Semin Neurosci 5:391-399.

Bargmann CI, Hung MC, Weinberg RA (1986) The neu oncogene encodes an epidermal growth factor receptor-related protein. Nature 319:226-230.

Ben-Baruch N, Yarden Y (1994) Neu differentiation factors: a family of alternatively spliced neuronal and mesenchymal factors. Proc Soc Exp Biol Med 206:221-227.

Bosenberg MW, Massague J (1993) Juxtacrine cell signaling molecules. Curr Opin Cell Biol 5:832-838.

Bradley WG, Asbury AK (1970) Duration of synthesis phase in neurilemma cells in mouse sciatic nerve during degeneration. Exp Neurol 26:275-282.

Bray GM, Vidal-Sanz M, Aguayo AJ (1987) Regeneration of axons from the central nervous system of adult rats. Prog Brain Res 71:373-379.

Brockes JP, Lemke GE, Balzer Jr DR (1980) Purification and preliminary characterization of a glial growth factor from the bovine pituitary. J Biol Chem 255:8374-8377.

Brockes JP, Breakefield XO, Martuza RL (1986) Glial growth factor-like activity in Schwann cell tumors. Ann Neurol 20:317-322. 
Burgess TL, Ross SL, Qian Y-X, Brankow D, Hu S (1995) Biosynthetic processing of neu differentiation factor: glycosylation, trafficking and regulated cleavage from the cell surface. J Biol Chem 270:19188-19196.

Carraway KLI, Cantley LC (1994) A neu acquaintance for erbB3 and erbB4: a role for receptor heterodimerization in growth signaling. Cell 78:5-8.

Chen MS, Bermingham-McDonogh O, Danehy Jr FT, Nolan C, Scherer SS, Lucas J, Gwynne D, Marchionni MA (1994) Expression of multiple neuregulin transcripts in postnatal rat brains. J Comp Neurol 349:389-400.

Chomczynski P, Sacchi N (1987) Single-step method of RNA isolation by acid guanidinium thiocyanate-phenol-chloroform extraction. Anal Biochem 162:156-159.

Clemence A, Mirsky R, Jessen KR (1989) Non-myelin-forming Schwann cells proliferate rapidly during Wallerian degeneration in the rat sciatic nerve. J Neurocytol 18:185-192.

Cohen JA, Yachnis AT, Arai M, Davis JG, Scherer SS (1992) Expression of the neu proto-oncogene by Schwann cells during peripheral nerve development and Wallerian degeneration. J Neurosci Res 31:622-634.

Corfas G, Rosen KM, Aratake H, Krauss R, Fischbach GD (1995) Differential expression of ARIA isoforms in the rat brain. Neuron 14:103-115.

Dong Z, Brennan A, Liu N, Yarden Y, Lefkowitz G, Mirsky R, Jessen KR (1995) Neu differentiation factor is a neuron-glia signal and regulates survival, proliferation and maturation of rat Schwann cell precursors. Neuron 15:585-596.

Falls DL, Rosen KM, Corfas G, Lane WS, Fischbach GD (1993) ARIA, a protein that stimulates acetylcholine receptor synthesis, is a member of the neu ligand family. Cell 72:801-815.

Fawcett JW, Keynes RJ (1990) Peripheral nerve regeneration. Annu Rev Neurosci 13:43-60.

Feinberg AP, Vogelstein B (1984) A technique for radiolabeling DNA restriction endonuclease fragments to high specific activity. Anal Biochem 67:15-28.

Flickinger TW, Maihle NJ, Kung H-J (1992) An alternatively processed mRNA from the avian c-erbB gene encodes ligand-dependent transformation. Mol Cell Biol 12:883-893.

Freeman RS, Estus S, Johnson Jr EM (1994) Analysis of cell cyclerelated gene expression in postmitotic neurons: selective induction of cyclin D1 during programmed cell death. Neuron 12:343-355.

Friede RL, Johnstone MA (1967) Responses of thymidine labeling of nuclei in gray matter and nerve following sciatic transection. Acta Neuropathol (Berl) 7:218-231.

Gassman M, Casagranda F, Orioli D, Simon H, Lai C, Klein R, Lemke G (1995) Aberrant neural and cardiac development in mice lacking the erbB4 neuregulin receptor. Nature 378:390-394.

Goodearl ADJ, Davis JB, Mistry K, Minghetti L, Otsu M, Waterfield MD, Stroobant P (1993) Purification of multiple forms of glial growth factor. J Biol Chem 268:18095-18102.

Goodearl ADJ, Yee AG, Sandrock Jr AW, Corfas G, Fischbach GD (1995) ARIA is concentrated in the synaptic basal lamina of the developing chick neuromuscular junction. J Cell Biol 130:1423-1434.

Gubler U, Hoffman BJ (1983) A simple and very efficient method for generating cDNA libraries. Gene 25:263-269.

Haley JD, Kinchington D, Whittle N, Waterfield MD, Ullrich A (1987) The epidermal growth factor receptor gene. In: Oncogenes, genes and growth factors (Guroff G, ed), pp 41-76. New York: Wiley.

Hall SM, Gregson NA (1977) The effects of mitomycin C in the process of regeneration in the mammalian peripheral nervous system. Neuropathol Appl Neurobiol 3:65-78.

Ho W-H, Armanini MP, Nuijens A, Phillips HS, Osheroff PL (1995) Sensory and motor neuron-derived factor: a novel heregulin variant highly expressed in sensory and motor neurons. J Biol Chem 270:14523-14532.

Holmes W, Young JZ (1942) Nerve regeneration after immediate and delayed suture. J Anat 77:63-96.

Holmes WE, Sliwkowski MX, Akita RW, Henzel WJ, Lee J, Park JW, Yansura D, Abadi N, Raab H, Lewis GD, Shepard HM, Kuang W-J, Wood WI, Goeddel DV, Vandlen RL (1992) Identification of heregulin, a specific activator of p185erbB2. Science 256:1205-1210.

Jessen KR, Mirsky R (1991) Schwann cell precursors and their development. Glia 4:185-194.

Jessen KR, Brennan A, Morgan L, Mirsky R, Kent A, Hashimoto Y, Gavrilovic J (1994) The Schwann cell precursor and its fate: a study of cell death and differentiation during gliogenesis in rat embryonic nerves. Neuron 12:509-527.

Jin J-J, Nikitin AY, Rajewsky MF (1993) Schwann cell lineage-specific neu (erbB-2) gene expression in the developing rat nervous system. Cell Growth Differ 4:227-237.

Jo SA, Zhu X, Marchionni MA, Burden SJ (1995) Neuregulins are concentrated at nerve-muscle synapses and activate ACh-receptor gene expression. Nature 373:158-161.

Kimura H, Fischer WH, Schubert D (1990) Structure, expression and function of a schwannoma-derived growth factor. Nature 348:257-260.

Lee K-F, Simon H, Chen H, Bates B, Hung M-C, Hauser C (1995) Requirement for neuregulin receptor erbB2 in neural and cardiac development. Nature 378:394-398.

Levi ADO, Bunge RP, Lofgren JA, Meima L, Hefti F, Nikolics K, Sliwkowski MX (1995) The influence of heregulins on human Schwann cell proliferation. J Neurosci 15:1329-1340.

Lubinska L (1964) Axoplasmic streaming in regenerating and in normal fibers. Prog Brain Res 131:1-66.

Luetteke NC, Phillips HK, Qiu TH, Copeland NG, Earp HS, Jenkins NA, Lee DC (1994) The mouse waved-2 phenotype results from a point mutation in the EGF receptor tyrosine kinase. Genes Dev 8:399-413.

Maniatis T, Fritsch EF, Sambrook J (1990) Molecular Cloning: A Laboratory Manual. Cold Spring Harbor, NY: Cold Spring Harbor Laboratory Press.

Marchionni MA (1995) neu tack on neuregulin. Nature 378:334-335.

Marchionni MA, Goodearl ADJ, Chen MS, Bermingham-McDonogh O, Kirk C, Hendricks M, Danehy F, Misumi D, Sudhalter J, Kobayashi K, Wroblewski D, Lynch C, Baldassare M, Hiles I, Davis JB, Hsuan JJ, Totty NF, Otsu M, McBurney RN, Waterfield MD, Stroobant P, Gwynne D (1993) Glial growth factors are alternatively spliced erbB2 ligands expressed in the nervous system. Nature 362:312-318.

Marikovsky M, Lavi S, Pinkas-Kramarski R, Karunagaran D, Liu N, Wen D, Yarden Y (1995) ErbB-3 mediates differential mitogenic effects of $\mathrm{NDF} /$ heregulin isoforms on mouse keratinocytes. Oncogene 10:1403-1411.

Meyer D, Birchmeier C (1994) Distinct isoforms of neuregulin are expressed in mesenchymal and neuronal cells during mouse development. Proc Natl Acad Sci USA 91:1064-1068.

Meyer D, Birchmeier C (1995) Multiple essential functions of neuregulin in development. Nature 378:386-390.

Morrissey TK, Levi ADO, Nuijens A, Sliwkowski MX, Bunge RP (1995) Axon-induced mitogenesis of human Schwann cells involves heregulin and p185erbB2. Proc Natl Acad Sci USA 92:1431-1435.

Moscoso LM, Chu GC, Gautam M, Noakes PG, Merlie JP, Sanes JR (1995) Synapse-associated expression of an acetylcholine receptorinducing protein, ARIA/heregulin, and its putative receptors, erbB2 and erbB3, in developing mammalian muscle. Dev Biol 172:158-169.

Nadim W, Anderson PN, Turmaine M (1990) The role of Schwann cells and basal lamina tubes in the regeneration of axons through long lengths of freeze-killed grafts. Neuropathol Appl Neurobiol 16:411-421.

Oaklander AL, Miller MS, Spencer PS (1987) Rapid anterograde spread of premitotic activity along degenerating cat sciatic nerve. J Neurochem 48:111-114.

Orr-Urtreger A, Trakhtenbrot L, Ben-Levy R, Wen D, Rechavi G, Lonai P, Yarden Y (1993) Neural expression and chromosomal mapping of Neu differentiation factor to $8 \mathrm{p} 12-\mathrm{p} 21$. Proc Natl Acad Sci USA 90:1867-1871.

Peles E, Yarden Y (1993) Neu and its ligands: from an oncogene to neural factors. Bioessays 15:815-824.

Pellegrino RG, Politis MJ, Ritchie JM, Spencer PS (1986) Events in degenerating cat peripheral nerve: induction of Schwann cell S phase and its relation to nerve fibre degeneration. J Neurocytol 15:17-28.

Perry VH, Brown MC (1992) Role of macrophages in peripheral nerve degeneration and repair. Bioessays 14:401-406.

Pinkas-Kramarski R, Shelly M, Glathe S, Ratzkin BJ, Yarden Y (1996) Neu differentiation factor/neuregulin isoforms activate distinct receptor combinations. J Biol Chem 271:19029-19032.

Plowman GD, Whitney GS, Neubauer MG, Green JM, McDonald VL, Todaro GJ, Shoyab M (1990) Molecular cloning and expression of an additional epidermal growth factor receptor-related gene. Proc Natl Acad Sci USA 87:4905-4909.

Plowman GD, Culouscou J-M, Whitney GS, Green JM, Carlton GW, Foy L, Neubauer MG, Shoyab M (1993) Ligand-specific activation of HER4/p180erbB4, a fourth member of the epidermal growth factor receptor family. Proc Natl Acad Sci USA 90:1746-1750.

Raivich G, Kreutzberg GW (1993) Peripheral nerve regeneration: role of growth factors and their receptors. Int J Dev Neurosci 11:311-324.

Sandrock Jr AW, Goodearl ADJ, Yin Q-W, Chang D, Fischbach GD 
(1995) ARIA is concentrated in nerve terminals at neuromuscular junctions and at other synapses. J Neurosci 15:6124-6136.

Schubert D, Heinemann S, Carlisle W, Tarikas H, Kimes B, Patrick J, Steinbach JH, Culp W, Brandt BL (1974) Clonal cell lines from the rat central nervous system. Nature 249:224-227.

Shah NM, Marchionni MA, Isaacs I, Stroobant P, Anderson DJ (1994) Glial growth factor restricts mammalian neural crest stem cells to a glial fate. Cell 77:349-360.

Shindler KS, Roth KA (1996) Double immunofluorescent staining using two unconjugated primary antisera raised in the same species. J Histochem Cytochem 44:1331-1335.

Tonge DA, Golding JP (1993) Regeneration and repair of the peripheral nervous system. Semin Neurosci 5:385-390.

Trachtenberg JT, Thompson WJ (1996) Schwann cell apoptosis at devel- oping neuromuscular junctions is regulated by glial growth factor. Nature 379:174-177.

Wen D, Peles E, Cupples R, Suggs SV, Bacus SS, Luo Y, Trail G, Hu S, Silbiger SM, Ben Levy R, Koski RA, Lu HS, Yarden Y (1992) Neu differentiation factor: a transmembrane glycoprotein containing an EGF domain and an immunoglobulin homology unit. Cell 69:559-572.

Wen D, Suggs SV, Karunagaran D, Liu N, Cupples RL, Luo Y, Janssen AM, Ben-Baruch N, Trollinger DB, Jacobsen VL, Meng S-Y, Lu HS, Hu S, Chang D, Yang W, Yanigahara D, Koski RA, Yarden Y (1994) Structural and functional aspects of the multiplicity of neu differentiation factors. Mol Cell Biol 14:1909-1919.

Xu YH, Ishii S, Clark AJ, Sullivan M, Wilson RK, Ma DP, Roe BA, Merlino GT, Pastan I (1984) Human epidermal growth factor receptor cDNA is homologous to a variety of RNAs overproduced in A431 carcinoma cells. Nature 309:806-810. 